NBER WORKING PAPER SERIES

\title{
MERGER POLICY AND INNOVATION: MUST ENFORCEMENT CHANGE TO ACCOUNT FOR TECHNOLOGICAL CHANGE?
}

\author{
Michael L. Katz \\ Howard A. Shelanski \\ Working Paper 10710 \\ http://www.nber.org/papers/w10710 \\ NATIONAL BUREAU OF ECONOMIC RESEARCH \\ 1050 Massachusetts Avenue \\ Cambridge, MA 02138 \\ August 2004
}

The views expressed herein are those of the author(s) and not necessarily those of the National Bureau of Economic Research.

(C2004 by Michael L. Katz and Howard A. Shelanski. All rights reserved. Short sections of text, not to exceed two paragraphs, may be quoted without explicit permission provided that full credit, including $(\subset$ notice, is given to the source. 
Merger Policy and Innovation: Must Enforcement Change to Account for Technological Change? Michael L. Katz and Howard A. Shelanski

NBER Working Paper No. 10710

August 2004

JEL No. L4

\begin{abstract}
Merger policy is the most active area of U.S. antitrust policy. It is now widely believed that merger policy must move beyond its traditional focus on static efficiency to account for innovation and address dynamic efficiency. Innovation can fundamentally affect merger analysis in two ways. First, innovation can dramatically affect the relationship between the pre-merger marketplace and what is likely to happen if a proposed merger is consummated. Thus, innovation can fundamentally influence the appropriate analysis for addressing traditional, static efficiency concerns. Second, innovation can itself be an important dimension of market performance that is potentially affected by a merger. We explore how merger policy is meeting the challenges posed by innovation.

Michael L. Katz

Walter A. Haas School of Business

University of California, Berkeley

Berkeley, CA 94720-1900

katz@haas.berkeley.edu

Howard A. Shelanski

Boalt Hall School of Law

University of California, Berkeley

Berkeley, CA 94720-7200

shelanski@law.berkeley.edu
\end{abstract}






II. DEFINING “INNOVATION” IN A MERGER CONTEXT ............................5

III. A BRIEF REVIEW OF THE U.S. LEGAL PROCESS AND PREVIEW OF THE ISSUES RAISED BY INNOVATION............................. 9

A. LEGAL AND ECONOMIC UNDERPINNINGS........................................................... 9



1. Market Definition ..................................................................................... 13

2. The "Analysis" of Market Shares ............................................................ 15

3. The Analysis of Other Market Conditions ............................................ 16



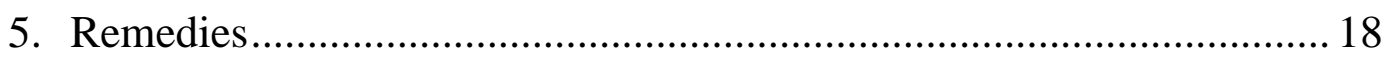

C. The Interaction of Merger Policy and Intellectual

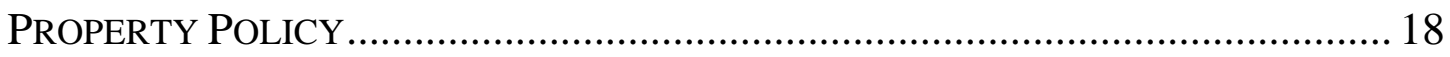

IV. THE IMPACT OF INNOVATION ON COMPETITION................................ 20

A. MARKET DEFINITION.......................................................................................... 21

B. The Use of MARKet Share IN Dynamic MARKeTS ........................................ 24

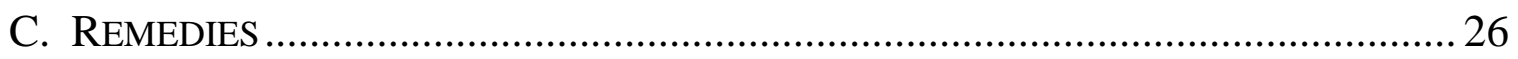

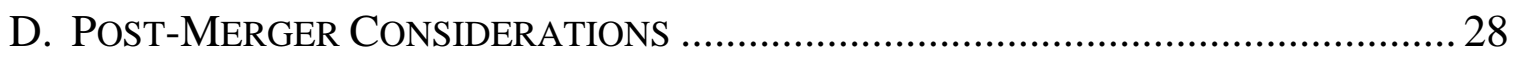

V. THE IMPACT OF COMPETITION ON INNOVATION_..............................30

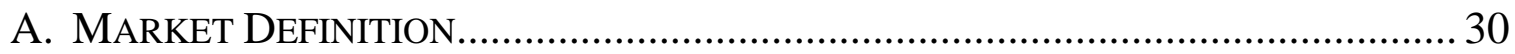

B. Market Share AND the CONCENTRATION-COMPETITION

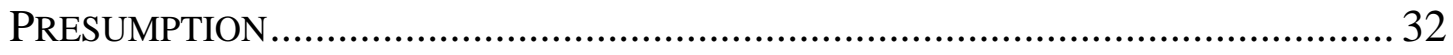

C. Other MARKET CHARACTERISTICS AND COMPETITIVE EFFECTS ANALYSIS 
D. INNOVATION: TOO MUCH OF A GOOD THING? ................................................ 41

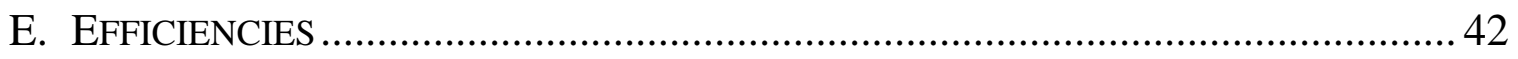

1. Potential Sources of Efficiencies ............................................................... 43

2. Merger Specificity …………………………....................................... 46

3. Tensions between Efficiency and Consumer Welfare............................. 46

4. Developing Reliable Projections of Consumer Benefits ........................ 48

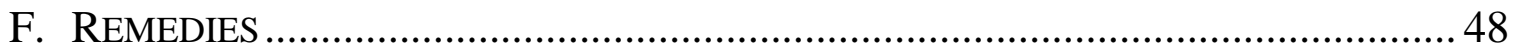

G. SCHUMPETERIAN COMPETITION AND MERGER Policy ....................................... 49

VI. INNOVATION CASES..................................................................................... 51

A. EARly MERger Cases: Starting to TAKe InNOVATION

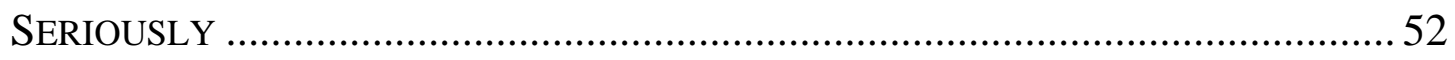

B. Transitional Cases: InNovation Moves to the Fore................................ 56





C. Recent Case Developments: More Nuanced Analysis ........................... 62

VII. CONCLUSION: TOWARDS DYNAMIC MERGER POLICY ....................66 


\section{INTRODUCTION}

Merger policy is the most active area of U.S. antitrust policy. From 1991 to 2002, for example, the Antitrust Division of the U.S. Department of Justice conducted an average of 161 merger investigations each year, which is more than all of the Division's other civil and criminal investigations combined. ${ }^{1}$ Merger investigations constitute a similarly important part of the Federal Trade Commission’s “Maintaining Competition Mission.”2

Traditionally, merger policy focused on the question of whether a proposed transaction would lead to higher or lower prices, based on a static analysis that compared market power and efficiency effects. Dynamic considerations such as research and development, while not altogether absent, played relatively little role. ${ }^{3}$ Today, innovation is widely recognized as an important driver of national economic welfare. Productivity growth driven by technological change has been credited with stimulating the major economic expansions of the 1960's, 1980's, and 1990's. ${ }^{4}$ Although precise estimates of the particular percentages of economic output or growth that can be attributed to innovation are hard to make, there is strong consensus among

There were an average of 131 other investigations per year. U.S. Department of Justice, Antitrust Division, Workload Statistics 1991-2002. Non-merger antitrust actions include criminal prosecutions of price-fixing cartels, as well as civil actions against individual companies that are found to have engaged in anticompetitive practices (e.g., the Microsoft case).

2 See, Federal Trade Commission, Fiscal Year 2002 Congressional Budget Justification (April 9, 2001), available at: $<$ http://www.ftc.gov/os/2001/04/2002budgetjustification.pdf $>$, at 46-60.

3 Innovation considerations were raised in some early non-merger cases. United States v. Aluminum Co. of Amer., 148 F.2d 416, 427 (2d Cir. 1945) recognized the effects of market power on innovation, although innovation concerns did not play a significant role in the decision. Innovation played a more central role in United States v. Automobile Manufacturers Ass'n, 307 F. Supp. 617, 618 (C.D. Cal. 1969), in which the court found that the leading American automobile manufacturers had engaged in a conspiracy "to eliminate competition in the research, development, manufacture and installation of motor vehicle air pollution control equipment ... " in violation of Section 1 of the Sherman Act (aff'd in part and appeal dismissed in part, 397 U.S. 248 (1970)).

4 See, e.g., Economic Report of the President 2000, at 35. 
policy makers and economists that innovation is a critical component of a sustained, healthy economy.

The consensus about the value of innovation has spread to antitrust policy. It is now well recognized by antitrust enforcement officials that investment in research and the diffusion of innovations are among the most important dimensions of market performance. One official observed that "the more important that innovation becomes to society, the more important it is to preserve economic incentives to innovate," 5 and another observed that, "as important as price competition is to us, a second major and possibly even greater concern is maintaining competition for innovation.”6 Merger policy has thus increasingly focused on innovation, although exactly what that means or how it translates into enforcement has proven difficult to get a handle on.

In this paper, we examine the developing role of innovation in U.S. merger policy. Considerations of innovation are central to merger policy in at least two ways. First, because dynamic efficiency is critical to successful economic performance, there can be considerable interest in the effects of a merger on innovation. In other words, innovation can itself be an important dimension of market performance that is potentially affected by a merger. Merging parties frequently assert that the transaction will allow them to engage in greater innovation, while antitrust enforcers may object to a transaction on the grounds that it will lead to a loss of competition that would otherwise spur innovation. In order fully to assess the impact of a merger on market performance, merger authorities and courts must examine how a proposed

51999 Annual Report, Antitrust Division, U.S. Department of Justice, at 5.

6 “Antitrust Considerations in International Defense Mergers,” Address by Robert Kramer, Chief, Litigation II Section, Antitrust Division, U.S. Department of Justice (May 4, 1999), at 3. 
transaction changes market participants' incentives and abilities to undertake investments in innovation. We will refer to this first role for innovation in merger policy as the "innovation incentives" criterion.

A second way in which innovation is central to antitrust policy is that the presence of innovation can fundamentally alter the nature of the appropriate analysis even if one focuses on traditional performance measures, such as static pricing efficiency. In brief, merger analysis forms a prediction of a proposed transaction's effects on consumer welfare by examining present characteristics of the parties to the transaction and the market setting in which those parties operate. Innovation can dramatically affect the relationship between the pre-merger marketplace and what is likely to happen if the proposed merger is consummated. For example, market shares are often used as a measure of market power. But, in theory at least, significant innovation may lead to the rapid displacement of a supplier that, by traditional measures such as current market share, appears to be dominant. This raises the broad question of how merger analysis should form predictions about the likely competitive effects of a proposed transaction. We will refer to this second role for innovation in merger analysis as the "innovation impact" criterion.

Under the innovation incentives criterion, one asks how the change in market structure and competition brought about by a merger will likely affect consumer welfare through effects on the pace or nature of innovation that might reduce costs or bring new products to consumers. Under the innovation impact criterion, the situation is reversed. It refers not to how market structure will affect innovation, but to how innovation will affect the evolution of market structure and competition. Innovation is a force that could make static measures of market 
structure unreliable or irrelevant, and the effects of innovation may be highly relevant to the kind of remedy antitrust authorities choose to adopt.

The two ways that innovation may factor into merger analysis have important policy implications. To the extent that innovation is itself a significant objective, antitrust agencies need to understand the relationship between market structure and innovation in a given case with sufficient rigor to distinguish legitimate from merely opportunistic claims that the merger will benefit, or at least not harm, innovation incentives. Similarly, the fact that innovation may affect the post-merger marketplace in ways that are hard to predict challenges merger authorities to devise ways to distinguish mere claims by the merging parties that they face potential competition due to innovation from situations in which such potential entry really exists. Finally, the importance of innovation incentives raises the question of whether the enforcement guidelines and precedent aimed at promoting conventional competitive goals of low prices and high output are consistent with the promoting the goal of efficient innovation. ${ }^{7}$ To the extent there is tension between innovation and static economic goals of merger policy, merger enforcement will have to develop a framework for deciding how to make tradeoffs between those objectives. If merger authorities wish to take a more dynamic approach to maximizing consumer or social welfare, our analysis suggests that merger policy should strengthen its basic framework by adding to its current set of tools and by developing a more sophisticated approach for incorporating uncertainty about future economic events into decision making.

In this chapter, we explore both of the avenues through which innovation affects, and is affected by, merger policy. We begin, in Section II, by considering three illustrative scenarios of 
the impact of innovation on the central concerns of merger policy. As background, in Section

III, we review the established framework for merger enforcement. We then examine in Sections IV and V how successfully that framework is likely to be in addressing the different challenges related to innovation. To illustrate how these challenges are met in practice, in Section VI we discuss and evaluate several merger cases in which the antitrust agencies have focused on innovation. We conclude with some observations about the current relationship between merger policy and innovation and about the possible evolution of that relationship.

\section{DEFINING “INNOVATION” IN A MERGER CONTEXT}

Implicit in any discussion of how innovation might factor into merger analysis is a definition of "innovation." The concept of innovation can span a spectrum of activities ranging from pure research aimed at making discoveries in basic science to developmental activities that apply known scientific results to improve existing products or production processes. The closer the innovation at issue in a particular merger is to resulting in an identifiable, predictable product, the more likely the issue for merger review will be how the innovation will affect future structure and performance in the product market relevant to the transaction (i.e., the innovationimpact criterion). The farther the innovation is from a tangible result, the more likely the question for merger authorities will be how the transaction will affect the likelihood and level of continued investment in R\&D (i.e., the innovation-incentives criterion). To illustrate further how the question for merger policy changes as the nature of the innovation changes, we next

7 Of course, from a long-run perspective, promoting innovation and promoting low quality-adjusted prices are largely the same objective. The distinction we draw in the text can be viewed as one between static pricing efficiency and dynamic pricing efficiency. 
discuss three abstract cases that show the different problems that different forms of innovation present for merger review.

Case 1: Innovation that is well underway to create or improve defined products and processes. We begin by considering situations in which the innovation efforts of the merging parties and their rivals are largely complete. ${ }^{8}$ In some cases, the firms may already be productmarket competitors, with ongoing R\&D efforts aimed at improving existing products and processes. In other cases, the firms seeking to merge may not yet be competitors in any product market, but these firms may be developing products that will enable the firms to compete with one another in one or more product markets in the future. Where innovation efforts are well under way but have not yet resulted in a tangible product, the ongoing innovation may serve as evidence to support treating the merging firms as potential competitors: firms that have made substantial investment and progress toward entering a market are much more predictable entrants than are firms that merely could undertake such investment.

In the settings just described, the potential harms from a merger arise not from the elimination of competing $R \& D$, but rather from the elimination of future product-market competition between the merging parties. Hence, the focus of merger analysis is the conventional one of product-market competition rather than anything specially to do with innovation. However, the presence of not-yet-complete innovative efforts complicates the predictions of how the merger will affect product-market competition. This is so because the central task for merger analysis is to form predictions about what competition will look like in the future, with and without the merger. In the case of merging firms that do not yet compete in

8 This case is, admittedly, somewhat artificial. Actual markets are likely to have ongoing waves of innovation. 
a product market, there will tend to be a lack of definitive evidence about cost and demand conditions on which to base predictions of the state of competition. Even where firms are already product-market competitors, ongoing R\&D efforts may be likely to change the future competitive positions of one or more suppliers. The potentially dramatic effects of innovation can greatly increase the difficulty of predicting a merger's effects on price competition.

Case 2: Innovation-based race to market dominance. We next consider situations in which the innovation efforts of the merging parties and their rivals are the focus of the merger analysis, and product-market competition is largely unaffected by the merger. Such situations arise when firms are undertaking competing R\&D efforts and the "winner" of this R\&D competition will achieve market dominance because of a patent, the realization of network effects, or some other winner-take-all phenomenon. If the process literally is winner-take-all, then the question of how the merger affects product-market competition, which lies at the heart of conventional merger analysis, simply does not arise. In these situations, the post-innovation product market is monopolized, whether or not the proposed merger is consummated. The public policy concern here is whether the merger will diminish R\&D competition and thus either retard the introduction of a new product or result in a product that offers consumers smaller net benefits.

In some markets subject to strong technological progress, this process may play itself out repeatedly. That is, competition may take the form of a succession of "temporary monopolists" who displace one another through innovation. At any one time, there is little or no head-to-head price competition. But there is significant innovation competition over time. This pattern of competition is often referred to Schumpeterian rivalry, after Joseph Schumpeter, who asserted that it is a central feature of the modern economy. As we shall discuss below, some observers 
have questioned whether central elements of conventional merger analysis are at all helpful in understanding Schumpeterian competition.

Case 3: Commercially rational delay in competitive innovation. Our final case illustrates the fact that there can be a tension, and hence the need to make a tradeoff, between static and dynamic policy objectives. When successful innovation cannot be protected from replication or imitation by competitors, perhaps because of weak intellectual property rights, a firm may not race for the lead but instead wait for another firm to do the hard work that the waiting firm can then copy. If all firms reason this way, then no firm will want to take the lead and subsidize its competitor's R\&D, and the result will be a waiting game. Innovation will be delayed, possibly forever. In this case, antitrust agencies may face a choice between (1) allowing the waiting firms to merge and internalize the free-riding problem, which would then hasten innovation but end product-market competition, and (2) blocking the merger, which would preserve product-market competition for existing products but might permanently delay the development and introduction of new products. In other words, the choice is whether to promote long-run innovation or protect short-run product pricing competition.

As we discuss below, actual enforcement choices may not be as polarized as in this hypothetical. In particular, alternative institutions, such as research joint ventures-under which competing suppliers jointly invest in innovation and share the results among themselves—may allow firms to cooperate in the conduct of $R \& D$ while remaining product-market competitors. Hence, the evaluation of these alternative institutions may be an important component of merger analysis in certain situations where innovation is an important dimension of market performance.

Each of the three cases above implies a distinct kind of merger inquiry and hence illustrates the different ways in which innovation could factor into merger policy. The first two 
cases above represent the ends of a spectrum that begins with conventional considerations of actual or potential competition in product markets, where innovation serves as supporting evidence, and runs all the way to cases in which innovation is the sole or central concern of the merger analysis. The third case illustrates that there can be situations in the middle where there potentially are significant tradeoffs between static and dynamic competition or there is a need to evaluate alternative institutions in terms of both types of efficiency considerations simultaneously.

\section{A BRIEF REVIEW OF THE U.S. LEGAL PROCESS AND PREVIEW OF THE ISSUES RAISED BY INNOVATION}

To understand the implications of innovation for the application of merger policy, we next present a brief survey of the current U.S. merger review process and its substantive guidelines. Although our focus is on the United States, it is worth observing that the European Commission and many other competition policy agencies in other nations have modeled their merger review processes in whole or in part on the U.S. approach.

\section{A. Legal and Economic Underpinnings}

The choice of welfare standard is a central feature of any public policy toward mergers. Economists generally favor some notion of economy-wide efficiency, while the statutes often are interpreted as imposing a consumer-welfare standard. ${ }^{9}$ Although some antitrust commentators write as if the pursuit of economic efficiency and the maximization of consumer welfare are

$9 \quad$ Under the total welfare standard, efficiency gains benefit firms and, insofar as they are passed on in lower prices or higher quality, also their customers. Both are equally valued. See, Oliver Williamson (1968) "Economies as an antitrust defense: the welfare trade-offs," American Economic Review, 58:18-36. Under the alternative consumer welfare standard, the competition authority takes into account only those benefits passed on to consumers. 
identical objectives, they are not. ${ }^{10}$ The critical difference is that an economic efficiency objective considers the effects of actions on the welfare of both producers and consumers, while a consumer-welfare standard considers only the latter. As we will discuss below, the choice between these two standards can have profound effects on merger analysis, particularly when innovation is significant.

The fundamental premise of merger policy, and of antitrust policy in general, is that increased competition results in improved economic performance. ${ }^{11}$ Specifically, antitrust policy is grounded on the belief that competitive markets do the best job of producing and delivering at the lowest feasible prices the goods and services consumers want. The vast majority of mergers that are challenged in the U.S. by federal antitrust agencies are challenged under Section 7 of the Clayton Act, which makes it illegal for one company to acquire some or all of the assets of a competitor where the effects "may be substantially to lessen competition, or to tend to create a monopoly." 12

Both the Antitrust Division of the U.S. Department of Justice ("Justice Department”) and the Federal Trade Commission ("FTC”) are charged with enforcing the Clayton Act. The Justice Department can seek to block a merger by filing a complaint in federal district court. The FTC

10 See, e.g., Damien J. Neven and Lars-Hendrik Roller (2000) "Institution Design: The Allocation of jurisdiction in international antitrust.” European Economic Review, 44: 845-855.

11 See, e.g., Antitrust Enforcement and the Consumer, available at: $<$ http://www.usdoj.gov/atr/public/div_stats/9142.pdf> (2001), §§ 1, 2, 4; Antitrust Guidelines for Collaborations Among Competitors on the FTC web site (04/2000), available at:

$<$ http://www.ftc.gov/os/2000/04/ftcdojguidelines.pdf $>$, at 1, 4, 6.

1215 U.S.C. § 18. Mergers can also be challenged under §1 of the Sherman Act, 15 U.S.C. §1, which bars "[e]very contract, combination in the form of trust or otherwise, or conspiracy in restraint of trade or commerce among the several States, or with foreign nations." 
can bring a case before its own administrative law judges or in a federal district court. ${ }^{13}$ The cases filed in district court only rarely proceed to trial. Typically an agency’s filing of a complaint either causes the merger to be called off or to be resolved through a consent decree that incorporates remedies against potential post-merger harm to competition. Examples of each outcome, respectively, are the recently scuttled merger between Echostar and DirecTV, against which the Justice Department filed a complaint in 2003, and the merger between Pfizer and Warner-Lambert, completed in 2000 subject to remedies after the FTC filed a complaint against that transaction.

The Justice Department and FTC have issued a set of Horizontal Merger Guidelines, ( "Merger Guidelines”) that purport to provide a blueprint for how the agencies will conduct their analysis of a merger. ${ }^{14}$ It should be observed that the Merger Guidelines do not have the force of law and, indeed, the Merger Guidelines explicitly (and accurately) state that the agencies may pursue different lines of argument in litigation. ${ }^{15}$ Nonetheless, the Merger Guidelines are broadly adopted by the agencies and the courts. ${ }^{16}$

13 In addition, there can be private challenges to mergers (although they face antitrust-injury and standing hurdles), which may be motivated by very different considerations than governmental challenges. Our focus here is on public policy. U.S. Department of Justice and the Federal Trade Commission, Horizontal Merger Guidelines, rev. April 8, 1997 (hereafter, Merger Guidelines).

15 Merger Guidelines, §0.1.

$16 \quad$ See, e.g., Jonathan B. Baker (2003) "Responding to developments in economics and the courts: Entry in the merger guidelines,” Antitrust Law Journal 71:189-206, and David Scheffman, Malcolm Coate, and Louis Silvia (2003) "Twenty years of merger guidelines enforcement at the FTC: An economic perspective,” Antitrust Law Journal 71: 277-318 (2003). 
In practice, merger policy in the United States focuses on how the merging parties' combination will affect concentration in one or more relevant markets. ${ }^{17}$ This is done because an increase in concentration in the relevant product and geographic markets is taken as a proxy for a decrease in competition that—if large enough—will lead to a significant increase in the prices faced by consumers. ${ }^{18}$ In U.S. v. Philadelphia National Bank, for example, the Supreme Court defined the relevant product as a cluster of services that constitute "commercial banking” and defined the relevant geographical market as the four-county area in which the merging parties had offices. ${ }^{19}$ The Court held that a merger between the region's first and second largest banks, which would have given the merged entity a 35 percent market share measured in terms of assets, created impermissible concentration and had to be enjoined. ${ }^{20}$ As we shall discuss, there is ongoing debate on the degree to which changes in concentration levels are good predictors of the likely competitive effects of a merger, especially when innovation is an important feature of the industry under examination.

\section{B. The Legal Analytical Process}

There is a largely standardized process by which courts evaluate mergers when the agencies bring legal challenges. We briefly outline the stages in that process.

17

Merger Guidelines, §§ 1.0, 1.5. See, also See, e.g., FTC v. University Health, Inc., 938 F.2d 1206, $1211 \mathrm{n}$. 12 (11th Cir.1991); FTC v. PPG Industries, Inc., 798 F.2d 1500, 1503 (D.C.Cir.1986); FTC v. Staples, Inc., 970 F.Supp. 1066, 1081-82 (D.D.C.1997).

18

19

For the most part, economic theory and antitrust policy have long favored more competition over less for the purpose of lowering prices, expanding output, and making consumers better off. There are, however, limited exceptions to this view. For example, certain industries, in which per-unit cost declines as output increases to the point that it is most efficient to have just one firm producing all output in a given market, have come to be known as "natural monopolies." Historically, telecommunications networks were a leading example, and public policy actually served to limit entry. That view has since changed. For instance, the Telecommunications Act of 1996, 47 U.S.C. §§ 151 et seq, seeks to promote competitive entry.

374 U.S. 321 (1963). 


\section{Market Definition}

Market share calculations typically play a central role in merger litigation. In order to calculate shares, it is necessary to define the relevant market of which various suppliers have shares. $^{21}$ Thus, defining the boundaries of one or more markets with respect to their product and geographic scopes is a first step under the Merger Guidelines and is typically also an issue early in any antirust case in the U.S. courts. ${ }^{22}$

A long-standing principle by which economists define the product scope of a market is to include two goods or services in the same relevant market if consumers view them as sufficiently close substitutes and not to include them in the same relevant market if consumers do not view them as sufficiently close substitutes. ${ }^{23}$ A similar logic is used for geographic scope. When are substitutes "sufficiently" close to be included in the same market? To some extent, chocolates compete with automobiles for consumers' dollars, but one should not conclude that chocolates and automobiles are in the same product market. To give more precision to the concept of sufficiently close substitutes, economists undertaking market delineation exercises often conduct a so-called hypothetical monopolist test. This test asks whether a hypothetical, profitmaximizing monopolist over a group of products in a given area could profitably raise price above a specified level by a 'small but significant' amount for a sustained period of time. ${ }^{24}$ The

Id. Brown Shoe Co. v. United States, 370 U.S. 294 (1962) See, e.g., Merger Guidelines, § 1; Toys R Us v. FTC, 221 F.3d 928 ( $7^{\text {th }}$ Cir. 2000).

See, e.g., George W. Stocking and Willard F. Mueller (1955) "The Cellophane Case and the New Competition,” American Economic Review 45:29-63 at 44-48.

Merger Guidelines, § 1.0; FTC v. Swedish Match, 131 F. Supp. 2d 151, 160 (D.D.C. 2000); California v. Sutter Health Systems, 130 F. Supp. 2d 1109, 1120 (N.D. Cal. 2001). See, also, Michael L. Katz and Carl Shapiro (2003) "Critical loss: Let’s tell the whole story,” Antitrust Spring:49-56 at 53. 
group of products considered in the test is a candidate relevant market. The smallest group of products that satisfies the test constitutes a relevant market. ${ }^{25}$

A price increase will raise a hypothetical monopolist's profits unless unit sales volume falls sufficiently to offset the higher price received for the units sold. ${ }^{26}$ Thus, the hypothetical monopolist test indicates that a set of products or a geographical area constitutes a relevant market if the hypothetical monopolist could make a small but significant and non-transitory increase in price without causing enough consumers to switch to substitute goods that the price increase becomes unprofitable.

The hypothetical monopolist test is used both by enforcement agencies and by the courts that review agency actions. The U.S. Court of Appeals for the Eighth Circuit, for example, reversed the FTC's injunction of a merger between two hospitals in a single town on the grounds that the FTC had failed to show that its narrow definition of the relevant market could satisfy the hypothetical monopolist test. ${ }^{27}$

Although the courts and enforcement agencies emphasize defining relevant markets, it is widely believed among economists that a proper economic analysis does not require formal market definition and that an over-reliance on the mechanics of market definition can be an obstacle to good analysis. Professor Jonathan Baker, a former Director of the U.S. Federal Trade Commission’s Bureau of Economics, observed:

Indeed, if a merger can be shown to harm competition directly, antitrust should not need to spend much effort on market definition ... [I]f the likely harm to competition from a merger can be demonstrated directly, there exists a market where harm will occur, but there is little need to specify the market’s precise

$25 \quad$ Merger Guidelines, $§ \S 1.0$ and 1.11.

26 We are assuming that the baseline price is greater than or equal to incremental cost.

27 FTC. v. Tenet Healthcare Corp., 186 F.3d 1045 (8 ${ }^{\text {th }}$ Cir. 1999). 
boundaries. $^{28}$

Similarly, Professor Janusz Ordover, a former Deputy Assistant Attorney General for Economic Analysis at the Department of Justice, wrote:

From the perspective of economic theory, antitrust law's preoccupation with market definition has always seemed somewhat peculiar. Arguments for and against a merger that turn upon distinctions between broad and narrow market definitions are, to an economic purist, an inadequate substitute for, and a diversion from, sound direct assessment of a merger's effect. ${ }^{29}$

Nonetheless, market definition continues to play an important role in practice. Indeed, it is often said that the outcome of merger litigation turns almost entirely on whether the market is defined narrowly or broadly. ${ }^{30}$

\section{The "Analysis" of Market Shares}

Once a relevant market has been defined, one can calculate shares. Legally, there is a rebuttable presumption that a high resulting level of concentration indicates a competitive problem. ${ }^{31}$ In addition, the Department of Justice and the FTC often take increases in concentration as a reason to be concerned about a merger when deciding whether to pursue an enforcement action. ${ }^{32}$ There is no general theorem of economics proving that higher concentration leads to higher prices or less output. There are, however, a number of reasons to expect this relationship absent innovation. First, many, but not all, formal economic models of markets likely to attract merger scrutiny (i.e., those markets in which only a few firms compete)

Jonathan Baker (1997) “Contemporary Empirical Merger Analysis,” George Mason Law Review, 5:347361.

Janusz A. Ordover and Daniel M. Wall (1989) "Understanding Econometric Methods of Market Definition,” Antitrust, 3:20-25 at 20-21 [footnote omitted].

See, e.g., Richard G. Parker (1998) “Trends in Merger Enforcement and Litigation, § 2,” available at: $<$ http://www.ftc.gov/speeches/other/parker.htm>.

United States v. Philadelphia National Bank, 374 U.S. 321 (1963). 
indicate that equilibrium output falls and equilibrium prices rise as the number of firms declines. This is especially true in markets where firms cannot quickly and easily adjust output levels as they vie to take the market share of the exiting firm. Empirically, there is substantial evidence to support the theoretical correlation of prices and market concentration, ${ }^{33}$ as U.S. consumers have readily experienced in such markets as long-distance and wireless telephone services, air travel, and pharmaceuticals. To be sure, in other models and under specified conditions, increased concentration may not lead to higher prices and entry may not lead to lower prices. Hence, the use of market shares as only the starting point for the analysis of market power.

\section{The Analysis of Other Market Conditions}

If the plaintiffs establish that a merger will lead to high levels of concentration, then the defendants attempt to rebut the presumption of a competitive problem by pointing to other factors, such as the possibility of entry by new competitors or certain market characteristics that can make it difficult to raise prices (e.g., the presence of large, sophisticated buyers who can exert bargaining pressure). As the Merger Guidelines recognize, "market share and concentration data provide only the starting point for analyzing the competitive impact of a merger.”34 A complete analysis considers both the abilities and incentives of competitors to expand their output levels and/or change the attributes of their products in response to price changes by the merging parties that would harm consumers.

\footnotetext{
$32 \quad$ See Merger Guidelines, § 1.5.

33 See, e.g., Richard Schmalensee (1989) “Inter-Industry Studies of Structure and Performance,” in Handbook of Industrial Organization, Vol. II, Schmalensee and Willig (ed.s), Amsterdam: North Holland.

$34 \quad$ Merger Guidelines, §2.0.
} 


\section{Efficiencies}

If the analysis of market shares and other market characteristics demonstrates that a proposed merger will not give rise to a significant competitive problem, one can conclude that the merger will not harm competition and consumers. But if a significant competitive problem is predicted by the preceding stages of analysis, then one must conduct another stage of review to predict correctly whether a proposed merger will benefit or harm consumers. Simply put, a merger that is expected to give the merging parties the ability to raise prices profitably might nonetheless lead to lower prices or at least to greater social welfare if the merger gives rise to sufficient cost savings of the right sort. These cost savings are referred to as 'efficiencies. ${ }^{35}$

Not all cost savings count as efficiencies. First, there is a requirement that the savings be merger specific. ${ }^{36}$ If there is a simple, arms-length transaction that would allow the parties to reap the cost savings in some way that would not raise competitive concerns, then those cost savings do not justify the merger. As should be readily apparent, it often can be very difficult to assess whether there is a practical alternative for realizing the cost savings. More generally, it is typically very difficult to predict with any certainty the magnitude of cost savings likely to result from a proposed merger because doing so entails making predictions about the results of combining complex operations and corporate cultures.

The Merger Guidelines describe the process as follows:

The Agency will not challenge a merger if cognizable efficiencies are of a character and magnitude such that the merger is not likely to be anticompetitive in any relevant market. To make the requisite determination, the Agency considers whether cognizable efficiencies likely would be sufficient to reverse the merger's potential to harm consumers in the relevant market, e.g., by preventing price increases in that market. [§4, Internal footnote omitted.] 


\section{5. $\quad$ Remedies}

Several public policy responses are available if analysis indicates that the effect of a merger in its proposed form may be substantially to lessen competition or to tend to create a monopoly. One, of course, is simply to block the transaction. Often, however, less drastic steps are available that can allow a modified version of the transaction to take place. In theory, such remedies allow the realization of efficiencies while averting the harms that might otherwise arise from the loss of competition between the two merging suppliers. Potential remedies include the divestiture of assets where competitive overlaps are particularly significant, the mandatory licensing of intellectual property to other firms to allow them to compete more effectively with the merging parties, and limitations on the merged firm's conduct (e.g., a requirement to offer the same prices to all customers to prevent the merged firm from targeting customers whose only practical options were the two merging suppliers).

\section{The Interaction of Merger Policy and Intellectual Property Policy}

Merger policy is part of a broader legal framework governing business behavior.

Intellectual property law is another part of that framework of particular relevance to the interaction of merger policy and innovation. There are various methods for obtaining intellectual property rights, including in-house invention, licensing, and merger. Patents, copyright, and trademarks all are assets subject to Clayton Section 7. Even though intellectual property rights are sometimes said to give the holder the right to a monopoly, there is no free pass for a merger because it involves intellectual property. 
In the past, a widely held view was that there was a fundamental tension between intellectual property rights and antitrust policy, such as merger enforcement. ${ }^{37}$ In this view, intellectual property rights regimes create monopolies to spur innovation, while merger policy seeks to prevent monopolies from forming. The modern view holds that both intellectual property policy and merger policy seek to promote consumer welfare by creating an economic environment in which innovative activities are stimulated by both competition and the promise of returns to successful innovation. ${ }^{38}$ In this regard, both sets of policies have something else in common: the relationships between public policy, market structure, and innovation are complex, and it is sometimes difficult to know what policy best promotes innovation and consumer welfare.

The intellectual property rights regime can interact with merger enforcement in interesting ways. The presence of strong intellectual property rights regimes, such as patent and copyright, may facilitate licensing by increasing the extent to which licensing contracts are enforceable. In contrast, licensing can be very difficult in situations where intellectual property is protected through secrecy. For instance, a seller cannot afford to reveal its technology to a potential licensee because the licensee may then simply appropriate the information. And it is also difficult to limit a licensee’s further dissemination of the information. The feasibility of licensing due to a strong intellectual property rights regime has at least two consequences for merger policy. First, when the primary efficiencies claimed for a merger involve intellectual proscribe unreasonable restraints of competition, the patent laws reward the inventor with a temporary monopoly that insulates him from competitive exploitation of his patented art”).

See, e.g., Atari Games Corp. v. Nintendo of America, Inc., 897 F.2d 1572, 1576 (Fed. Cir. 1990)(“[T]he aims and objectives of patent and antitrust laws may seem, at first glance, wholly at odds. However, the two bodies of law are actually complementary"). 
property assets, the question arises whether licensing could serve as a less restrictive alternative to a full merger. Second, when licensing is feasible, it can be used in fashioning a remedy to a proposed merger that raises significant concerns of competitive harms.

The fact that licensing can form the basis for merger remedies suggests that intellectualproperty policy and merger policy can be complementary. A firm may merge and still reap the benefits of its innovation through licensing royalties, while that same licensing can preserve competition in innovation that the transaction would otherwise harm. Moreover, as our later discussion of specific mergers will show, licensing remedies have become an important tool in the review and clearance of mergers in which innovation is a central feature. Only if one takes the extreme position that IP-related competitive harm can never form the basis for blocking a merger, ostensibly on grounds that such a basis would constitute a limitation of the IP right, do merger policy and IP policy necessarily come into conflict.

\section{THE IMPACT OF INNOVATION ON COMPETITION}

The merger-review process described in Section III has well-known problems that arise whether or not innovation is significant. In the present section and the one following, we identify particular challenges created by the presence of significant innovation. In the present section, we address how the presence of significant actual or potential innovation affects application of the legal analytical framework to the consideration of product-market competition and traditional, static pricing concerns. In the next section, we will consider the issues that arise for the legal analysis when one attempts to evaluate a merger in terms of its effects on innovation. 


\section{A. Market Definition}

Significant innovation raises two issues with respect to market definition for an analysis of static pricing efficiency. First, the hypothetical monopolist test typically is applied to price changes ranging from five to ten percent. Some have questioned the value of such a test in markets where quality-adjusted prices may fall 20 percent or more per year. We believe that this objection is readily dealt with in theory, although practice is somewhat more difficult. Second, and more important, rapid innovation can make it difficult to define relevant product markets because business executives and government officials alike may not yet know what the future products will be.

In American and European Union competition policy, a 'small but significant' price increase in the context of the hypothetical monopolist test is often taken to mean a price change in the range of five to ten percent. ${ }^{39}$ Several different criticisms have been made regarding 
application of this approach to markets with rapid technological progress, where prices might fall by 20 percent or more annually. ${ }^{40}$

One critique is that a five- or ten-percent price increase is "too small” when qualityadjusted prices are routinely changing by much greater amounts. ${ }^{41}$ However, neither those offering this critique, nor the Merger Guidelines themselves, discuss the rationale for considering a price increase of any particular size. It is apparent that the intent of the Guidelines' approach is to consider a price change that would have a significant effect on consumer welfare. It is less apparent that 10-percent increase becomes insignificant simply because the baseline is rapidly falling. One should also keep in mind that the hypothetical monopolist test is only one part of the competitive analysis.

Another criticism is that the hypothetical monopolist approach to defining market boundaries conducts a test based on the assumption that other suppliers hold their prices constant, when such prices may, in fact be falling. This criticism is somewhat misplaced: under the hypothetical monopolist test, the prices of potential substitute products are assumed not to change in response to a change in the monopolist's price, but this does not preclude the possibility of technological progress as a driver of price changes over time. The criticism does, however, raise an important question: what baseline prices for the hypothetical monopolist and

In addition to the issues in the text, Hartman et al. offer another criticism of the standard hypothetical monopolist approach to market definition. Their criticism, however, appears to be based on a misunderstanding of the Merger Guidelines. Hartmand et al. write that "During [the 1970s] a variety of [minicomputer] systems competed on price and performance while exhibiting price differences of several hundred percent. Strict interpretation of the Merger Guidelines suggests that such price differences imply that the products are in different markets." (Raymond Hartman, David Teece, Will Mitchell, and Thomas Jorde (1993) “Assessing Market Power in Regimes of Rapid Technological Change,” Industrial and Corporate Change, 2:317-350 at 323.) The hypothetical monopolist test, however, is based on the effects of price changes, not existing price differentials. 
other suppliers should be used in the defining the product scope of a market with rapid technological progress? Specifically, should one use current or future prices?

Because the concern of merger analysis is with post-merger market performance, there is an argument that it is more appropriate to use projections of future prices. Of course, forming reliable projections can sometimes be very difficult, and this difficulty can be compounded by the fact that innovation can itself be affected by the merger. And, when there is ongoing technological progress, the scope of the product market may continue to change, so that multiple projections are necessary. However, relying on current prices can lead to market definitions that are either too narrow (when there is rapid technological progress in substitute products) or too broad (when the hypothetical monopolist's product is subject to greater technological progress than are substitute products). ${ }^{42}$

A second difficulty that arises in defining relevant markets when innovation is important is more fundamental. The issue is that the agencies and the courts may not know which products will be viable substitutes in the near future. Under the traditional approach to market definition, whether using the hypothetical monopolist test or some other algorithm, the central aim is to identify existing products that are at present meaningful substitutes for one another from a consumer's perspective. When innovation is significant, the analysis may need to be much more forward looking. Innovation may result in the creation of new products that compete in the

See, e.g., Christopher Pleatsikas and David Teece (2001) "The Analysis of Market Definition and Market Power in the Context of Rapid Innovation,” International Journal of Industrial Organization, 19:665-693 at 671 .

42 For the latter reason, Pleatsikas and Teece are incorrect when they assert that "defining markets from a static perspective when innovation is rapid will inevitably lead to identification of markets that are too narrow.” (Pleatsikas and Teece, supra note 41, at 687. [Footnote citing D. Teece and M. Coleman (1998) "The Meaning of Monopoly: Antitrust Analysis in High Technology Industries," Antitrust Bulletin, 43:801-857 at 826-828, omitted.]) 
relevant market, or innovation may lower the costs of producing existing products that are, at present, too expensive to be considered viable substitutes for the products of the merging parties.

The brevity of our discussion should not be taken as a sign that this problem is minor or readily dealt with. Conceptually, the issues are straightforward and are compatible with the Merger Guidelines' market definition framework, as long as that framework is applied on a forward-looking basis. ${ }^{43}$ However, the practical difficulties of projecting future substitution possibilities in a fast-changing and highly uncertain environment should not be minimized.

\section{B. The Use of Market Share in Dynamic Markets}

Once a market has been delineated, the suppliers participating in that market can be identified and one can develop a measure or measures of market shares. The difficulties identifying future substitutes discussed in the previous subsection have important analogues in identifying market participants and calculating market shares.

Relatively little attention tends to be paid to the identification of competitors in most merger analyses, perhaps because this part of the analysis is relatively easy or at least is perceived to be a simple counting exercise once market boundaries have been set. The conventional focus is on actual rather than potential competitors, the latter of which are included in the market only when certain conditions of imminence and probability are met. But when innovation is important, identifying potential innovation and product-market competitors may be particularly critical to understanding competition. Identifying potential competitors is often

difficult, and competitive potentiality in the innovation context often hinges on the possession of certain skills and information assets that can be particularly hard to identify and measure. In the 
other direction, the existence of ongoing innovation efforts can render claims of potential product-market competition more readily verifiable.

Innovation also raises a fundamental question with respect to the calculation and interpretation of market shares as predictors of the static price and output effects of a merger. ${ }^{44}$ That question is whether current product-market shares are meaningful predictors of future competitive conditions and thus relevant to the prediction of the price and output effects of a merger. If a market is in constant turmoil due to dramatic innovation, the argument goes, then what does one learn from current product sales?

Even absent innovation, there are reasons to be cautious about the interpretation of market share data. In order to generate sensible predictions of the effects of a merger, the measurement and analysis of market shares should always be tied to a coherent theory of competitive effects that fits the facts of the industry under consideration. ${ }^{45}$ Put another way, the analysis of market shares can most confidently be used to predict adverse competitive effects of a merger when one has an empirically supported theory that market shares are informative of competitive conditions and that an increase in concentration will harm competition and consumers.

In general, high market share does not in itself suffice to show market power. One reason is that many market share measures are backward-looking (e.g., shares of installed base) or at best contemporaneous (e.g., shares of sales to customers who are new to the industry). As such,

43 In this regard, there is some tension between a forward-looking approach and the Merger Guidelines’ treatment of entry, which tends to take a limited perspective. (Merger Guidelines, § 3.)

44 And, of course, the issues that innovation raises for the definition of relevant markets affect the resulting calculation of market shares.

$45 \quad$ Under the process described by the Merger Guidelines, "Market shares will be calculated using the best indicator of firms’ future competitive significance.” Merger Guidelines, §1.41. 
market shares reflect where firms were or are, but not necessarily where they are going. This is a particularly critical shortcoming in industries characterized by significant innovation and dramatic technological change. Innovation may render market shares unstable and hard to predict. Even if the merged firms would have a dominant market share immediately post-merger, another firm in the market could produce the next great new advance and leave the merged entity behind. $^{46}$ Indeed, market shares may be altogether irrelevant in some cases because there may be markets in which innovation is so characteristic and sustained that firms compete not just for market share, but for markets as a whole. A firm's monopoly today may say little about the firm's prospects one, two, or five years from now.

The Merger Guidelines recognize that in changing markets current market share may be an inaccurate measure of a firm's forward-looking competitive significance. ${ }^{47}$ There is a strong consensus among economists that rival suppliers' capacity to enter and expand in a market must be considered in addition to market share data. It is especially imperative in markets characterized by innovation that merger enforcement agencies look beyond market share data.

\section{Remedies}

Innovation gives rise to intellectual property, which sometimes figures prominently in merger remedies. Merging firms sometimes agree to divest or license intellectual property to keep product-market competition from being lost. For example, in 2001, the U.S. Department of Justice filed a complaint challenging the proposed acquisition of DTM Corporation ("DTM") by

As discussed in Section V, the flip side of this is that a merger may have substantial effects on competition even if the post-merger market share is permissible within the enforcement guidelines. If the merger brings together two imminent technologies that otherwise would have competed, then consumers lose out on rivalry that otherwise would have come to exist absent the merger.

$47 \quad$ Merger Guidelines, §1.521. The extent to which the agencies are willing to adopt forward-looking views of competition is the subject of some debate. 
3D Systems Corporation ("3D"). ${ }^{48}$ The firms competed in the sale of rapid prototyping ("RP") systems, which transform a digitally encoded design into a three-dimensional object. The process can be used to produce models and even low-volume production quantities by what might be loosely thought of as three-dimensional laser printing.

Both 3D and DTM held extensive patent portfolios related to RP systems production that prevented firms that sold RP systems abroad from competing in the United States. As discussed in Section VI.C, below, the Department of Justice was concerned that the merger would significantly reduce competition. The Department of Justice and the parties reached a settlement that required 3D and DTM to grant a non-exclusive license to manufacture and sell products under the defendants' RP patent portfolios within specific fields of use. ${ }^{49}$ The idea was to allow a foreign supplier to enter the U.S. market as a replacement for the loss of an independent competitor through merger. The licensee was required to be a firm currently manufacturing industrial RP systems in a foreign market, so that it would have a demonstrated ability to compete. $^{50}$

As a general matter, there are two antitrust rationales for compulsory licensing: (a) to remedy a refusal to license that itself is held to be exclusionary and to constitute an antitrust violation, and (b) to ameliorate the effects of another action that is illegal or—absent licensing-

U.S. v. 3D Systems Corporation and DTM Corporation, Verified Complaint. U.S. v. 3D Systems Corporation and DTM Corporation, Final Judgement (Proposed). Intellectual property assets also were included in the divestitures required to settle U.S. v. Premdor U.S. Holdings, Inc. International Paper Company, and Masonite Corporation. Similarly, U.S. v Miller Industries involved acquisitions of tow truck companies holding important patents and led to a connsent degree with mandatory licensing. 
would be prohibited under the antitrust laws. Licensing as a remedy in a merger case falls into this second category.

It is useful to distinguish between a duty to deal and licensing as a remedy because they may have very different effects on incentives to innovate. A general duty to deal under antitrust law compromises the scope of intellectual property rights and may create $a$ priori disincentives to engage in certain innovative efforts. In contrast, compulsory licensing as a remedy that allows a merger to go through may not weaken innovation incentives and, theoretically, could even increase them. The reason is the following. Suppose that the licensing allows a merger to be completed that would otherwise be blocked. To the extent that licensing is a means of restoring competition that is less costly to the defendant than are alternatives (e.g., dissolving the merger), the defendant benefits from having created intellectual property that can be incorporated into a remedy. While it is far from evident that these positive effects on R\&D are significant, the argument does suggest that any negative incentive effects may be insignificant.

\section{Post-Merger Considerations}

Innovation considerations may also affect antitrust policy towards a merged entity after an acquisition is consummated. If a merger turns out to have anticompetitive effects, it is at least theoretically possible to "unscramble the eggs" and order the newly formed enterprise to break itself into its previous components or to divide along some other basis that will restore competition. Such divestiture is easier when the harm to competition stems from consolidation of physical assets that can be cleanly sold off. Post-merger divestiture is potentially a much messier prospect when the harm stems from consolidation of R\&D assets in the form of human capital. Although a firm can be ordered to sell off a research unit, employees cannot be required 
to remain with that unit, and the end result might be to weaken the merged entity without restoring competition.

There may also be difficult challenges in determining when and how the antimonopoly provisions of Section 2 of the Sherman Act should apply to innovative firms. ${ }^{51}$ Suppose a merged entity turns out to become dominant. Separating the degree to which the dominance flows from beneficial innovation or from anticompetitive actions can be difficult. Much of the public debate surrounding the Department of Justice’s pursuit of Microsoft, for example, involved precisely that question. Even defining a violation can be particularly difficult. Is integration of increasingly advanced functions into a product efficient innovation or anticompetitive tying or bundling? And once a violation is proven, it can be especially difficult to design a remedy in fast-moving environments of technological change. Antitrust authorities face the challenge of crafting remedies that constrain anticompetitive behavior without reducing innovation or network benefits that may have accrued to consumers.

The scope of this chapter does not allow a detailed analysis of how innovation affects application of antitrust laws generally. But the purpose of our brief discussion here is to show that, in considering the role antitrust might play in the post-merger environment, innovation cannot be ignored as a force there as well as in the merger context. The complexity that innovation may introduce into the possibilities for later antitrust scrutiny of the merged firm in turn lends particular importance to getting the merger review right in the first place.

51 For a discussion of the application of Section 2 to high-technology markets, see David S. Evans and Richard Schmalensee (2002) "Some Economic Aspects of Antitrust Analysis in Dynamically Competitive Industries,” in Innovation Policy and the Economy, Vol. 2, Jaffee, Lerner, and Stern (ed.s), Cambridge, MA: MIT Press. 


\section{THE IMPACT OF COMPETITION ON INNOVATION}

We next consider the issues that arise for the legal analytical process of merger review when one attempts to evaluate a merger in terms of its effects on innovation. As we shall discuss, incorporating innovation effects into the analysis poses fundamental challenges, although challenges that we believe ultimately can be met.

\section{A. Market Definition}

The purpose of defining relevant markets is to identify the boundaries of competition. When competition takes the form of innovation, there is a fundamental issue whether a focus on product markets is appropriate. An argument in favor of taking a product-market focus is that the ultimate aim of innovation is to create products and processes that allow the innovator (or its licensees) to compete successfully in one or more product markets. An argument against this approach is that the notion of a well-defined product market is too limiting because the successful products of the future cannot be predicted with any degree of certainty. A potential response is to consider markets defined in terms of innovation capabilities rather than specific products. But even here, one must ultimately tie the analysis to some notion of (potentially) competing products in order to know which innovation capabilities are important. One way of reconciling these two views is to observe that product markets matter, but that future boundaries and the possibility of potential competition play much greater roles than in static analyses.

Consider two firms wishing to merge that have strong R\&D capabilities in similar areas, but that are not significant product-market competitors with one another, either because they do not compete in any product market in common or because the markets in which they do compete with one another are unconcentrated. From the standpoint of static price competition, there is presumptively no public policy rationale for blocking the merger. But if the firms are the only 
two, or among the few firms, that have the capability to undertake substantial innovation efforts, then the antitrust agencies might nonetheless be concerned with the consumer-welfare effects of the proposed merger.

Antitrust enforcers might be concerned either that: (1) the two firms would have otherwise engaged in competing $R \& D$ efforts that would have led to their becoming direct product-market competitors, or (2) the merged firm will reduce R\&D to the detriment of consumers. The first of these concerns is about potential competition in the particular product market(s) at issue in the merger. The second concern, however, is about innovation. Moreover, this concern arises even when —in the non-merger counterfactual—-the innovation under consideration might not lead to product-market competition. These two concerns raise legal and economic issues for market definition and the subsequent competitive effects analysis.

A first issue arises from the fact that potential competition cases are difficult to bring successfully in the United States. Courts tend to be skeptical of claims that a merger will harm consumers by reducing future competition between two merging firms that are not at present competing with one another. ${ }^{52}$ A second issue is that it may be extremely difficult to define a product market if one does not yet know what the product will be. In response to these difficulties, Richard Gilbert and Steven Sunshine, then working at the Department of Justice, introduced the concept of innovation markets. ${ }^{53}$ Instead of potential competition in product markets, the concept shifts attention to actual competition in innovation markets. As discussed General principles of antitrust law require "clear proof" or at least a "reasonable probability" that entry into the new market would in fact have occurred in the near future and disallow speculation about "ephemeral possibilities.” (United States v. Marine Bancorp, 418 U.S. 602, 617, 623 (1974); Tenneco, Inc. v. FTC, 689 F.2d 346, 352 (2d Cir. 1982); In re B.A.T. Industries, 104 F.T.C. 852, 919-928 (1984).)

53 Gilbert, Richard J., and Steven C. Sunshine (1995) "Incorporating Dynamic Efficiency Concerns in Merger Analysis: the Use of Innovation Markets.” Antitrust Law Journal, 63:569-601. 
above, one can question whether a separate concept is needed on the grounds that all competitive concerns ultimately tie to some market in which goods and services are offered to consumers. And, in practice, although innovation markets were used in United States v. General Motors Corp., since then they have been little mentioned. ${ }^{54}$

Whether or not a separate concept is useful, the underlying idea that the set of competitors is sometimes best identified by examining which firms have the skills and assets needed to compete effectively is a sound one. Thus, one of the challenges that arises in applying the current merger review framework to innovation is to adapt a concept of market definition based on consumers' substitution among existing products to one based on firms' capabilities to engage in innovation to create new substitute products. Under a forward-looking approach, instead of identifying what products compete with each other today and which firms produce those products, antitrust authorities would have to determine which assets and skills are needed to innovate and how many firms possess those skills and assets. These are fundamentally different inquiries, one of which is based on the behavior of consumers and the other of which is based on the capabilities of firms.

\section{B. Market Share and the Concentration-Competition Presumption}

Even if the market in which innovation takes place can be well defined, the question arises of how changes in market structure will affect performance of that market. The use of market share data to predict a merger's likely effects on innovation competition raises two fundamental issues. The first is whether one should consider concentration of product sales or concentration of $R \& D$ capabilities. $R \& D$ is conducted with an eye toward the future. Thus, one

54 We will return to this point in our review of selected innovation cases below. 
can raise serious doubts about the value of current product-market sales as indicia of the state of innovation competition. ${ }^{55}$ Moreover, the threat of entry or potential competition may be a stronger spur to innovation efforts than to lowering current prices and increasing current output. $^{56}$ Indeed, even R\&D programs that never succeed in developing new products or processes may nonetheless benefit consumers by stimulating potential rivals to innovate. Although these are important issues, they are similar to those just discussed in the context of market definition.

Our focus in the remainder of this section is thus on the second issue: is concentrationwhether measured by product-market sales or the number of viable R\&D competitors—a reliable basis for predicting the strength of innovation competition. Even if market shares were likely to remain stable post-merger and the transaction truly would concentrate the market in a sustained way, that concentration may affect innovation incentives differently from how it affects static economic variables like price and output.

A central tenet of merger policy is that markets characterized by atomistic competition generally promote consumer welfare better than do concentrated markets. ${ }^{57}$ The presumption that increased benefits come from an increased number of competitors is weaker, however, when the policy goal is not just lower prices for a given set of goods produced under a fixed set of

See, e.g., Kamien, Morton I., and Nancy L. Schwartz (1975) "Market Structure and Innovation: A Survey," Journal of Economic Literature, XIII:1-37, at 20, ("concentration reflects the current sellers of a product and may be quite unrelated to the extent of actual and potential rivalry in innovating new products".) See also, Evans and Schmalensee, supra note 51, at 16-18, and Hartman, Teece, Mitchell, and Jorde, supra note 40 , at 322 and 323.

56 Under the theory of "limit pricing" incumbent firms set low prices today to deter future entry. In many circumstances, however, the threat entry will have little effect pre-entry prices, and potential competition plays a relatively small role in price setting.

There are some exceptions. Even in static settings, for instance, perfect competition does not attain the first best in the presence of externalities, and distortions due to concentration may in some cases offset those due to externalities. 
technologies, but also efficient innovative activity by firms over time. Economic theory has long raised questions about the degree to which increased product-market competition or an increase in the number of firms undertaking R\&D leads to an increase in overall R\&D investment. ${ }^{58}$ Both the theoretical and empirical bases for predicting that an increase in concentration will lead to less innovation are mixed.

Consider, first, the theoretical basis. Economic theory identifies situations in which high market shares are conducive to R\&D investment. For instance, the possibility of sudden and sweeping entry, combined with large up-front investment demands, can necessitate high initial returns to allow costs to be recouped before the next innovator supplants the incumbent investor. A firm with a large market share and significant market power may better amortize the fixed costs of the R\&D and appropriate a high percentage of the R\&D's benefits. Conversely, it has been said that "[the] best of all monopoly profits is a quiet life,"59 and considerable anecdotal evidence suggests that competition drives organizations to be more innovative than do protected monopoly positions.

The idea that the economic conditions that maximize innovation over time may not be the same conditions that allocate resources efficiently in the short run was suggested over 50 years ago by Joseph Schumpeter, who wrote that, for purposes of promoting economic welfare, "perfect competition is not only impossible but inferior, and has no title to being set up as the stated that "Few, if any, economists maintain that perfect competition efficiently allocates resources for technical advance.” (Kamien and Schwartz (1975), supra note 55, at 2.) Today, economists have a deeper appreciation for licensing and other forms of innovation diffusion, so there might be less agreement with such a sweeping statement because there are multiple possible interpretations of what is meant by perfect competition in this context. John R. Hicks (1935) , “Annual Survey of Economic Theory: The Theory of Monopoly,” Econometrica $3: 1-20$, at 8 . 
model of ideal efficiency.” ${ }^{\text {"60 }}$ Schumpeter's argument that most technological innovation would come from large corporations with market power and organized R\&D operations implied that antitrust law’s ideal of competition could have substantial social costs over time. ${ }^{61}$

Theoretical research has shown that, depending on various conditions, either monopoly power or competition may leads to greater total innovation. ${ }^{62}$ Although Schumpeter wrote mostly about large firms, and their associated economies of scale for R\&D and ability to attract capital and talented scientists, his critique of perfect competition and discussion of the benefits of market power suggest that his ideal innovators were not only large, but dominant as well. Early theoretical explorations of Schumpeter's claim found that when the polar cases of monopoly and perfect competition were compared, the latter provided stronger incentives for cost-reducing innovations. ${ }^{63}$ Subsequent models found oligopoly_competition among a few firms - to be the market structure most conducive to development of new products and processes. $^{64}$

Joseph A. Schumpeter (1942) Capitalism, Socialism, and Democracy, New York: Harper \& Row, at 106.

Of course, antitrust policy's competitive ideal has evolved over time. When Schumpeter was writing, the ideal was rivalry among small, atomized economic actors. Any cooperation or concentration that deviated from that standard was inherently suspect. The Chicago School revolution did much to improve understanding of why different market structures might result in different contexts and, thereby, to reduce rigid adherence to the perfectly competitive model. Competition, because of its benefits for allocative efficiency, nonetheless remained the touchstone of antitrust policy.

Frederick M. Scherer (1992) "Schumpeter and Plausible Capitalism,” Journal of Economic Literature 30:1416-1433.

William Fellner (1951) “The Influence of Market Structure on Technological Progress,” Quarterly Journal or Economics 65:556-577, and Kenneth Arrow (1962) "Economic Welfare and the Allocation of Resources for Invention,” in The Rate and Direction of Inventive Activity, R.R. Nelson (ed.), New York: Princeton University Press.

Frederick M. Scherer (1967) "Research and Development Resource Allocation Under Rivalry,” Quarterly Journal of Economics 81:359-394; Morton Kamien and Nancy Schwartz (1972) "Timing of Innovations Under Rivalry,” Econometrica 40:43-60 (1972); Morton Kamien and Nancy Schwartz (1976) "On the Degree of Rivalry for Maximum Innovative Activity,” Quarterly Journal of Economics 90:245-260. 
Although there have been many advances and refinements to the model described above, ${ }^{65}$ much of the research on market structure and innovation has a straightforward intuition behind it. On the one hand, a firm facing strong product-market rivalry has incentive to develop new products and processes that will help it improve or defend its market position. Similarly, a firm engaged in a race with several others to develop a new, patentable technology, will be under pressure to act quickly in order to win the race. On the other hand, suppliers with many productmarket rivals may have less ability to appropriate the gains from innovation that make the investment worthwhile, either because their innovations are readily copied or invented around by rivals, or because atomistic competitors lack the other assets needed to exploit their innovations fully (e.g., a firm with a small share of the product market may not amortize its cost-reducing innovation over very many units of output). Similarly, if many firms are racing to obtain a patent, each firm may conclude that its chances of winning the race are sufficiently small that it is not profitable to invest as much in $\mathrm{R} \& \mathrm{D}$ as it would absent so many competitors.

Strong intellectual property rights can reduce some of the risks from innovation, specifically those associated with rapid imitation. And licensing may make if possible and profitable to diffuse an innovation throughout an industry with many firms. Even if intellectual property rights give the innovator a temporary monopoly, however, rivals may develop similar or better advances and may get around the originator's patent. This is a risk that exists for competitive firms and monopolists alike. But the risk that another firm will successfully innovate may grow with the number of firms competing in the relevant product market and, at some point, the expected return to innovation may not justify the cost.

65 See Scherer (1992), supra note 62, and Jennifer F. Reinganum (1989) "The Timing of Innovation: Research, Development, and Diffusion,” in Handbook of Industrial Organization, Vol. I, Schmalensee and 
A firm with significant product-market power or few R\&D rivals, by contrast, probably has a better chance of recouping $R \& D$ investment. Large, established firms might be particularly adept at marshaling resources for incremental innovation or for helping to bring a small firm’s invention to market. And even a profit-maximizing monopolist-especially an unregulated one- - has an incentive to engage in cost-reducing innovations. But, because a monopolist already has the market share for which competitive firms strive, it may have less incentive to pursue product innovations and improvements than firms facing competition. Further, a monopolist will have an incentive to innovate strategically to protect its monopoly by excluding rivals and by avoiding cannibalization of its existing business, perhaps delaying implementation of those innovations it does develop. It might therefore be a qualitatively inferior innovator from the perspective of consumers and overall economic welfare. ${ }^{66}$

Although economic intuition suggests an overarching presumption that innovation will be most intense in firms with a mix of competitive incentives and supra-competitive returns, it is also clear that, depending on assumptions, the theoretical balance could swing towards either greater competition or monopoly in a given case.

Unfortunately, empirical data do not resolve the ambiguous theoretical relationship between competition and innovation. Many analyses supported the Schumpeterian view by finding a positive correlation between market concentration and R\&D investment. ${ }^{67}$ Other

Willig (eds.), Amsterdam: North Holland.

66 It should be observed that, in terms of efficiency, the social value of innovation is the incremental improvement that it represents over the existing technology. Hence, the fact that a monopolist is concerned with cannibalization is not entirely indicative of an efficiency problem.

67 See, e.g., Edwin Mansfield (1968) Industrial Research and Technological Innovation, New York: Norton. 
analyses, however, found data to show concentration to have a negative effect on innovation. ${ }^{68}$ An early and influential study by F.M. Scherer indicated that both could be correct over a sufficiently large range of market structures because the relationship between innovation and concentration is non-linear. His study, which corroborated the theoretical intuition discussed above, found the relationship between market structure and innovation to follow an "inverted-U” pattern: innovation is observed to be low at high levels of competition, to reach its peak at intermediate levels of oligopoly (where the four leading firms control roughly half the market), and then to fall off as market structure approaches monopoly. ${ }^{69}$ Several studies replicated and confirmed Scherer’s results. $^{70}$

Later work, however, raised serious doubts about these findings. Indeed, in their review of the empirical literature, Cohen and Levin concluded that "Together, these results leave little support for the view that industrial concentration is an independent, significant, and important determinant of innovative behavior and performance.” 71 There are several reasons for exercising caution in the interpretation of the empirical literature. First, there are issues regarding the statistical significance of the parameter estimates leading to a U-shaped

Oliver E. Williamson (1965) “Innovation and Market Structure,” Journal of Political Economy, 73: 67-73; B. Bozeman and A.N. Link (1983) Investments in Technology: Corporate Strategy and Public Policy Alternatives; A.K. Mukhopadhyay (1985) "Technological Progress and Change in Market Concentration in the U.S., 1963-1977,” Southern Economic Journal, 52:141-149.

69 Frederick M. Scherer (1967) “Market Structure and the Employment of Scientists and Engineers,” American Economic Review, 57:524-531.

70 Richard Levin, Wesley Cohen and David Mowery (1985) "R\&D Appropriability, Opportunity, and Market Structure: New Evidence on Some Schumpeterian Hypotheses," American Economic Review Papers and Proceedings 75:20-24; J.T. Scott (1984) "Firm Versus Industry Variability in R\&D Intensity," in R\&D, Patents and Productivity, Zvi Griliches (ed.), Chicago: University of Chicago Press.

71 Wesley M. Cohen and Richard C. Levin (1989) “Empirical Studies of Innovation and Market Structure” in Handbook of Industrial Organization, Vol. II, Schmalensee and Willig (eds.), Amsterdam: North Holland, at 1078, citing Wesley Cohen, Richard Levin, and David Mowery (1987) "Firm Size and R\&D Intensity: A Re-Examination,” Journal of Industrial Economics 35:543-565. 
relationship and whether they are, in fact, picking up the effects of omitted variables such as technological opportunity. ${ }^{72}$ Second, extreme care must be taken interpreting cross-sectional studies because the causality between market structure and innovation rates can run in both directions. ${ }^{73}$ One detailed analysis of British data found that the higher profit expectations in concentrated markets increased innovative activity but that, over time, innovation reduced concentration levels in the sample industries. ${ }^{74}$ Many empirical studies fail to account for the fact that market structure itself might be affected by the perceived possibilities for innovation and that market structure might therefore be a result rather than a cause of innovation incentives. Moreover, the literature addressing how market structure affects innovation (and vice versa) in the end reveals an ambiguous relationship in which factors unrelated to competition play an important role.

The systematic presumption that favors increased competition for purposes of static pricing and output efficiency thus has no analog when it comes to creating the optimal conditions for innovation. By the same token, it should be observed that "Schumpeterian" claims that merger policy should favor increased concentration as a means of promoting innovation equally lacks firm empirical grounding. Where this leaves merger authorities is the

See Kamien and Schwartz (1975), supra note 55, at 20-22. Kamien and Schwartz summarized their survey of the empirical literature as follows: "In reviewing the diverse findings on research efforts and concentration, we find little consensus" (at 22), and "Our review of the impact of market structure on innovation has netted little more than reaffirmation of the early observation that both competitive pressures and market opportunity seem important.” (at 24). Somewhat surprisingly, they then concluded their survey with "A new empirically inspired hypothesis has emerged to the effect that a market structure intermediate between monopoly and perfect competition would promote the highest rate of innovative activity." (at 32).

73 In terms of theory, a recent demonstration of this possibility is provided in a paper by Jan Boone, which finds that an increase in the intensity of competition can drive a leading firm to increase its innovation by relatively more than its rivals and thus increase future concentration. (Jan Boone (2001) "Intensity of competition and the incentive to innovate,” International Journal of Industrial Organization, 19:705-726.) 
following. Meaningful general presumptions have not been identified: innovation is affected by a variety of market factors other than concentration, as well as variables related to a firm's regulatory status, products, and technologies. While more rivalry rather than less will often remain the applicable rule of thumb, enforcement authorities cannot as confidently presume as a matter of economic theory that more competition is good or that market power is bad for R\&D. Nonetheless, although it is impossible to make definitive general statements about the linkage between market structure and innovation, one often can make reasonable, unambiguous predictions about the effects of specific transactions or alternative institutional arrangements within a particular industry structure based on a fact-intensive investigation.

\section{Other Market Characteristics and Competitive Effects Analysis}

Even more so than with price competition, it is necessary to look beyond market share data to understand innovation competition. Here we make two points very briefly. One, for the reasons discussed above, it is important to understand the distribution of $\mathrm{R} \& \mathrm{D}$ assets among various actual and potential rivals. Second, there are reasons to predict that suppliers will find it more difficult to coordinate their strategies to reduce $R \& D$ investments than to raise prices in the static sense. Although the underlying principles are generally the same, R\&D activities have certain characteristics that give rise to differences in practice. For example, R\&D efforts may be more complex and more difficult for rivals to observe than are prices, and this greater complexity and difficulty observing actions both tend to make coordinated strategies more 
difficult. $^{75}$ Similarly, the stochastic nature of R\&D output can greatly increase the difficulty of reaching and monitoring an agreement to restrict $R \& D$ efforts.

\section{Innovation: Too much of a Good Thing?}

Once a merger's likely effect on innovation has been predicted, an issue arises that does not come up in the analysis of conventional, static concerns. Although it is extremely counterintuitive to many people, a large body of economics literature has established that profitmaximizing firms may invest more in $R \& D$ than is socially efficient. ${ }^{76}$ An important implication is that the social welfare effects of an innovation-reducing merger may be positive. This situation can arise, for example, in patent races due to "business stealing” effects. In a race to obtain a pharmaceutical patent, for example, preempting its rivals by a day may allow a pharmaceutical firm to obtain intellectual property rights whose value far exceeds the social benefits of having the patented drug available one day sooner. ${ }^{77}$ Moreover, in some cases, an innovation may allow a supplier to increase its share of the economic pie without increasing the total pie (e.g., a product or database innovation may facilitate price discrimination having these effects). Such an innovation might have private value for the innovator, but no overall social value.

In most cases, firms will have little incentive to over-invest in R\&D broadly. The theoretical possibility of excessive private incentives notwithstanding, as an empirical matter private incentives to invest in R\&D typically are too low. ${ }^{78}$ This situation arises because,

75 Kamien and Schwartz (1975), supra note 55, at 15, attribute this general idea to Galbraith.

$76 \quad$ For a survey, see Reinganum (1989), supra note 65.

77 Similar effects may arise when being first to market creates a durable advantage in terms of favorable consumer perceptions.

78 See, e.g., Zvi Griliches (1992) “The Search for R\&D Spillovers,” Scandinavian Journal of Economics 94(Supp.):29-47, and Charles I. Jones and John C. Williams (1998) "Measuring the Social Return to R\&D,” Quarterly Journal of Economics 113: 1119-1135. 
generally, private firms are unable fully to appropriate the benefits that their R\&D generates for the economy. ${ }^{79}$ Moreover, consumers almost always benefit from additional R\&D. Even in patent race models in which firms engage in more than the socially efficient levels of $R \& D$ expenditures, consumers would be better off if firms invested still more and thus brought the fruits of innovation to the market even faster. ${ }^{80}$ Finally, there is a specific set of conditions under which firms can have socially excessive incentives, and one can examine any particular market to determine if those conditions are present. Whether enforcement authorities would want to act when such conditions for over-investment in innovation hold, however, raises the possible tension between consumer welfare and social welfare when merger policy focuses on innovation rather than static competition. We discuss this possible tradeoff from allowing mergers that reduce inefficient innovation in the section below.

\section{E. Efficiencies}

Merging parties sometimes identify increased innovation capabilities as a significant efficiency that will result from their transaction. Thus, there can be a need to predict whether a merger will improve the combined firm's innovation capabilities in ways that will generate consumer benefits. This can be a difficult undertaking for several reasons. Indeed, the agencies themselves have expressed skepticism about this type of merger efficiency and have asserted that

Dennis Carlton and Robert Gertner point out that empirical studies generally compare average private and social returns, while the privately and socially optimal R\&D levels depend on marginal returns. (Dennis W. Carlton and Robert H. Gertner (2003) "Intellectual Property, Antitrust and Strategic Behavior" in Innovation Policy and the Economy, Vol. 3, Jafee, Lerner, and Stern (ed.s), Cambridge, MA: MIT Press.) In settings where R\&D investment is driven by preemption incentives, the private marginal returns may deviate from the private average returns by more than the marginal social returns deviate from the average social returns, suggesting that perhaps there is a problem of excessive private incentives. It is far from evident, however, that patent preemption incentives are of empirical significance in many industries. 
“Other efficiencies, such as those relating to research and development, are potentially substantial but are generally less susceptible to verification and may be the result of anticompetitive output reductions.",81

\section{Potential Sources of Efficiencies}

A first issue is how a merger will lower the costs of R\&D or in other ways increase the merging firms’ abilities to innovate successfully. There are at least three types of effect that the merging parties might asset: (a) increased capabilities realized by combining complementary assets; (b) larger firm size, which somehow gives rise to a greater ability to fund, or absorb the risks of, R\&D; or (c) less competition and greater product-market profits, which can then fund R\&D.

With respect to combining complementary assets, a fundamental issue is whether there is an alternative means (e.g., licensing of complementary intellectual property) that could achieve the same efficiencies without removing a competitor. Mergers have specific institutional features that may give rise to certain advantages in facilitating the exchange of complementary assets, but the issue needs careful attention on a case-by-case basis. ${ }^{82}$

There has been considerable debate about the relevance of firm size for innovation. ${ }^{83}$ Following Schumpeter, some observers have praised large enterprises for their superior ability to attract the financial and human capital, bear the risk, and recoup the investment required for

\footnotetext{
$81 \quad$ Merger Guidelines, § 4.

82 For a general comparison of alternative institutional arrangements, including merger, see Michael L. Katz (1995) “Joint Ventures as a Means of Assembling Complementary Inputs,” Group Decision and Negotiation, 4:383-400.

83 For an overview of the ambiguous relationship between firm size and innovation, see Wesley M. Cohen and Steven Klepper (1996) “A Reprise of Firm Size and R\&D,” The Economic Journal 106:925-951.
} 
sustained R\&D activities. ${ }^{84}$ Other analysts tout small firms as being more creative than larger, more bureaucratic enterprises. ${ }^{85}$ Many empirical studies have addressed the relationship between firm size and innovation. Most recent research yields a consensus that, in general, R\&D rises only proportionally with firm size, and only up to a point. ${ }^{86}$ The strength of the causal relationship between firm size and $R \& D$ remains somewhat questionable despite the observed correlations. Because many variables correlate with firm size, it is unclear in many studies whether firm size itself is a statistically significant factor in innovation. Although early studies did purport to find significance, ${ }^{87}$ others have found that when other firm and industry characteristics are factored in, firm size does not significantly affect R\&D investment. ${ }^{88}$ Moreover, when the focus of analysis shifts from innovation inputs such as R\&D expenditures to outputs such as patents, large firms show no advantage at all over small ones. ${ }^{89}$ Data matching R\&D investment with patent output has in fact shown that smaller firms produce more innovations per R\&D dollar and per employee than do large firms. ${ }^{90}$

John Kenneth Galbraith (1952) American Capitalism: The Concept of Countervailing Power; William D. Nordhaus (1969) Invention, Growth, and Welfare: A Theoretical Treatment of Technological Change.

Morton I. Kamien and Nancy L. Schwartz (1982) Market Structure and Innovation. Cambridge: Cambridge University Press; Cohen and Levin, supra note 71, at 1067.

Frederick M. Scherer (1965) "Firm Size, Market Structure, Opportunity, and the Output of Patented Inventions,” American Economic Review 55: 1097-1125.

Cohen and Levin (1989), supra note 71.

Cohen, Levin, and Mowery (1987), supra note 71, and Cohen and Levin (1989), supra note 71.

Franklin Fisher and Peter Temin (1973) "Returns to Scale in Research and Development: What Does the Schumpeterian Hypotheses Imply?” Journal of Political Economy 81:56-70; M.T. Kohn and J.T. Scott (1982) "Scale Economies in Research and Development: The Schumpeterian Hypothesis," Journal of Industrial Economics 30:239-249 (1982); Zoltan Acs and David Audretsch (1990) Innovation and Small Firms; Acs and Audretsch (1991) "R\&D, Firm Size, and Innovative Activity," in Innovation and Technological Change, Acs and Audretsch (eds.).

Acs and Audretsch (1991), supra note 89. 
The evidence overall thus suggests that, to the extent firm size has an effect on innovation, its magnitude and direction depend on associated industry-level variables and are susceptible to very few general presumptions. The results suggest that especially large firms like those created by some recent mergers will have no special tendency—nor any predictable reluctance - to engage in innovation, and that small, fringe firms may play important roles over time in technologically advancing markets. ${ }^{91}$

Lastly, consider the argument that greater product-market profits make it possible for firms to conduct additional R\&D. There are two interpretations of the profits-innovation linkage. One is that the potential for product-market profits generates innovation incentives. This is an issue about competitive effects and was addressed in subsection V.B above. The other interpretation is that current profits can generate free cash to finance R\&D efforts. This is more of a statement about the production of innovation, and we will treat it as a kind of efficiency. A first observation is that there is a remarkable and dangerous lack of a limiting principle in this argument. By this argument, for example, why not grant a monopoly in an unrelated market in order to generate the cash flow needed to conduct R\&D in the market of concern? Second, given the overall efficiency of U.S. capital markets, this argument is inherently suspect. It is not surprising that, in their review of the empirical some years ago, Kamien and Schwartz found that "In sum, the empirical evidence that either liquidity or profitability are conducive to innovative effort or output appears slim." 92

91 See, e.g., Jonathan Baker (1995) “Fringe Firms and incentives to Innovate,” Antitrust Law Journal 63:621641.

$92 \quad$ Kamien and Schwartz (1975), supra note 55, at 26. 


\section{2. $\quad$ Merger Specificity}

As noted above, the possible use of alternative institutional arrangements, such as research joint ventures, raises complex issues in determining whether the efficiencies are merger specific. These issues arise because, in theory, two firms might be able to separate cooperation regarding product-market activities from cooperation with respect to R\&D activities. Thus, in some cases an important element of merger analysis is to determine whether the parties need a merger rather than a research joint venture or some other form of research cooperation (e.g., intellectual property licensing) that does not limit product-market competition. Although based on just one industry, a recent empirical study suggests that this issue is an important one. Gugler and Siebert (2004) found that research joint ventures in the semiconductor industry may achieve innovation efficiencies that are comparable to those attained through merger, but may do so without having mergers' adverse effects on product-market competition. ${ }^{93}$

\section{Tensions between Efficiency and Consumer Welfare}

Consideration of efficiencies in merger review typically brings to the fore the difference between a consumer-welfare standard and an economic-efficiency, or total-surplus, standard. Under a consumer-welfare standard, cost savings are relevant only to the extent that they are passed on to consumers in the form of lower prices of better products. Thus, a consumer-welfare standard would not count as benefits any projected savings in corporate overhead that are predicted to have no effects on product prices. Nonetheless, such savings would represent real gains to the economy, and they would be counted as benefits under a total-surplus standard. 
The analysis of efficiencies from a static pricing perspective often focuses solely on variable costs, on the grounds that changes in fixed costs will not affect the calculation of profitmaximizing prices. However, a change in the "fixed" costs of innovation may trigger a change in the resulting level innovation (i.e., whether a project is undertaken or not) which then has consequences for consumer welfare. Consequently, it is important that fixed costs not be summarily excluded from the efficiencies analysis where innovation is at issue. Another way of describing this point is to state that it is important to remember that, over a long enough time horizon, everything is variable.

It should also be observed that, under an efficiency standard, one would take into account the fact that a merger might eliminate socially wasteful duplication of R\&D even if doing so did not speed up the date at which innovation occurred or reduce quality-adjusted product prices. Indeed, there are circumstances in which an economic efficiency standard would count as a benefit the fact that a merger slowed the rate of innovation from a socially excessive level, but a consumer surplus standard would find the merger harmful. If merger policy is going to focus more on innovation it may therefore have to deal with welfare tradeoffs that antitrust does not confront in conventional product-market competition cases.

One way to resolve the social welfare/consumer welfare tradeoff is to insist that the cost savings from any reduction in innovation be passed through in the form of lower prices to consumers, an issue that arises in the context of productive efficiencies in a static merger review framework. But in the conventional, static efficiencies situation, the consumer ideally gets the same product at a lower price post-merger. In contrast, when a merger reduces inefficient innovation, the consumer at best gets a different (less advanced) product at a lower price postmerger and the price reduction may not compensate for the difference in product characteristics. 
The inability to compensate consumers through pass-through of cost-savings is one consequence of the fact, discussed next, that there may be no correspondence between the magnitude of the R\&D investment and the magnitude of the resulting consumer-welfare benefit.

\section{Developing Reliable Projections of Consumer Benefits}

Efficiencies are typically difficult to project with any confidence, even when innovation is not an issue. And, for a number of reasons, innovation makes the task even more difficult. First, there is the large stochastic element of innovation and R\&D projects often have very long gestation periods. Second, as discussed above, the drivers of innovation are only imperfectly understood. Third, where efficiency leads to greater product innovation and consumers have heterogeneous valuations of quality, projecting net consumer benefits can be very complex. Finally, the extent that innovation involves discrete projects and fixed cost commitments, even a small change in fixed costs can lead to a large change in consumer welfare. This relationship holds when the cost change (or other merger efficiency) tips the balance in favor of a supplier's undertaking a discrete investment that generates a large amount of consumer surplus, such as the introduction of a new product. In principle, the consumer surplus generated by these new services made possible by an R\&D investment can exceed the merger-specific reduction in the costs of conducting the R\&D. Thus, the agencies have to be careful not to measure efficiencies purely in terms of cost savings.

\section{F. Remedies}

Merger remedies can involve the divesture or licensing of assets, including intellectual property, in order to maintain innovation competition. The challenge for merger policy in crafting remedies for cases in which innovation is central is to identify the right assets for 
divestiture or, where those assets are intellectual property, for licensing. In the case where, for example, two drugstore chains seek to merge, divestiture is in principle relatively straightforward: the parties must divest stores where the pre-merger firms have overlapping territories. To be sure there may be problems in assuring that those stores are divested in a way that maintains their competitive viability against the merged entity, but there tends to be relatively little problem in identifying what stores to divest.

The problem is much harder when the assets to be divested are intended to maintain competition in innovation. ${ }^{94}$ Which personnel are central to an innovation effort and in what parts of the company are they located? Is $R \& D$ conducted in such a way that it is severable for purposes of divestiture? What patents are needed for a particular R\&D effort and are there alternative technologies available? These questions are far from insurmountable, but they do point out the particular challenges that innovation creates for remedial merger policy, and these questions suggest that refocusing conventional analysis will be necessary for enforcement agencies in innovation cases.

\section{G. Schumpeterian Competition and Merger Policy}

As noted in Section II above, in some markets competition may take the form of Schumpeterian rivalry in which a succession of “temporary monopolists” displace one another through innovation. At any one time, there is little or no head-to-head price competition but there is significant ongoing innovation competition. The nature of Schumpeterian competition suggests to some observers that antitrust policy should be less concerned with attacking business practices that might generate increased monopoly profits by harming competition within a 
market, or should at least be more circumspect about doing so. ${ }^{95}$ However, there still is an issue whether specific practices harm competition for the market. Moreover, in the merger context, it is not at all clear that policy should not be more restrictive, rather than less.

Proponents of the view that governmental intervention should be limited in this type of market generally argue that merger policy is likely to make costly errors through enforcement that will have the unintended effect of slowing innovation. Moreover, the argument goes, in dynamic markets it is impossible to predict what is going to happen, current market positions are irrelevant to future competition, and at any point the market is going to be monopolized anyway. ${ }^{96}$ Therefore, the argument concludes, firms should be allowed to combine with relatively little antitrust intervention in dynamic markets.

The analysis of this chapter suggests that the claim for systematic laissez faire in such markets is not soundly grounded in economics. Indeed, there are reasons to think that a merger policy designed to foster and protect Schumpeterian competition might appear fairly restrictive when viewed through the lens of conventional merger analysis. It will not always or even often be true that the conditions that foster the intense investment in new technology that leads to sequential competition "for the market" will be produced by unchecked consolidation. Indeed,

In this regard, the divestiture of intellectual property to preserve product-market competition (see Section IV.C above), is more similar to the manufacturing/retailing paradigm than to the innovation paradigm.

For a discussion of antitrust policy toward single-firm conduct in markets characterized by Schumpeterian competition, see Evans and Schmalensee, supra note 51.

Judge Posner has offered a different view of the problem. He argues that high-tech mergers can be dealt with well by existing institutions and policies, but that high-tech unilateral conduct cases are problematical because the agencies and courts can neither bring sufficient technical expertise to bear on the issues nor move in a timely enough fashion given industry's rate of change. Richard A. Posner "Antitrust in the New Economy. Address by Judge Richard Posner, September 14, 2000,” Tech Law Journal, available at http://www.techlawjournal.com/atr/20000914posner.asp. 
Case 2 in Section II, above, is one in which a merger would be challenged precisely because it would otherwise undermine Schumpeterian competition.

Innovation would be the center of the inquiry designed to determine when innovation requires antitrust agencies to intervene and when to stand back. In order to understand a proposed merger's potential effects on Schumpeterian competition, one would need to ask which firms had the potential to be the next temporary monopolist. The current shares of most firms might well be largely irrelevant to this assessment. (The large share of the current temporary monopolist would be relevant insofar as it indicated what would be the status quo until the next wave of innovation comes crashing through the market.) But it would be a mistake to think the irrelevance of current market shares inexorably leads to "permissive” merger policy. For instance, the Schumpeterian approach might instead imply that the currently dominant firm should be allowed to merge with essentially no other firm because any other firm might be the next successful rival. Similarly, it might be socially optimal to block a merger between two firms that had no sales of the final product at present because each may be involved in beneficial R\&D that will make it the next market winner.

\section{INNOVATION CASES}

The U.S. antitrust agencies have by now reviewed a number of merger cases in which innovation has been an important factor. A review of those cases helps one to understand how far the agencies have been willing to incorporate innovation concerns into merger policy and also to assess the kinds of cases in which the agencies have been, or can be, successful in that enterprise. 


\section{A. Early Merger Cases: Starting to Take Innovation Seriously}

One of the first merger enforcement actions expressly motivated by innovation concerns occurred in 1990, when the FTC challenged Roche Holding's acquisition of Genentech as likely to lessen research and development in several biotech products. ${ }^{97}$ Some of the concerns the transaction raised were traditional ones of competition: for example, Roche was on the verge of becoming the major challenger to Genentech's dominant position in the market for products to treat human growth hormone deficiency. But more central to the FTC's complaint was that Roche and Genentech were actual competitors in the research and development of important therapies for the treatment of AIDS and HIV infection. Genentech was considered to be ahead of its rivals in the development of such treatments, and Roche was actively involved in a competing development effort. Concerns about how consolidation of actual R\&D efforts would affect the future product market and the pace of innovation drove the enforcement decision. ${ }^{98}$

In terms of the abstract cases we discussed above, the Roche/Genentech case appears to fit case 1 in Section II, in which the innovation concern is tied to potential competition in an identifiable product market. With respect to treatments for human growth hormone deficiency, Roche's potential competitive impact was imminent and reasonably certain. While the potential competition between Roche and Genentech in the AIDS/HIV therapy market was more speculative because both firms were still in the R\&D phase, the competing R\&D efforts were well under way and the FTC found strong evidence to support its prediction that the relevant product market would develop and that Roche and Genentech would be important competitors in

$97 \quad$ Roche Holdings, Ltd., FTC No. C3315 (filed November 18, 1990).

98 See Richard Gilbert and Steven Sunshine, supra note 53, at 580 for further discussion of this case. 
that market. The FTC's analysis was thus more one of potential competitive effects than of effects on innovation per se.

The Justice Department first challenged a merger on innovation grounds in 1993, when it investigated ZF Friedrichshafen’s proposed acquisition of General Motors’ Allison Division. ${ }^{99}$ Allison and ZF together produced 85 percent of the world output of heavy-duty automatic transmissions for trucks and buses, but actually competed head-to-head in few geographic markets. ${ }^{100}$ The Justice Department nonetheless concluded that even markets whose concentration would be unaffected by the merger would be harmed by the transaction's reduction in Allison and ZF's incentives to develop new designs and products. ${ }^{101}$ This case therefore reflects the economic conclusion that near-monopoly levels of concentration are bad for innovation even in the absence of any changes in static efficiency and in the absence of any specific development effort that could be identified as being compromised.

The Roche/Genentech and ZF/Allison cases both considered innovation as an issue distinct from competition in an existing product market, but there were important differences. The FTC did not have to predict that there would be a reduction in rival innovation efforts from the increase in industry concentration that would have resulted from the acquisition. Rather, the increase in concentration was accompanied by concrete evidence that Roche was at an advanced stage in developing a competing human growth hormone treatment and that Roche and Genentech were the most promising of a small group of companies racing to develop certain AIDS/HIV treatments. Given that Roche appeared to have reached a point where its entry into

\footnotetext{
$99 \quad$ United States v. General Motors Corp., No. 93-530 (D. Del., filed November 16, 1993).

100 Id.

101 Id.
} 
the growth hormone market was no longer speculative, the question there was more a conventional one of competition than of innovation.

The FTC, however, framed the issue with respect to AIDS/HIV therapies purely as one of innovation. The FTC's focus was on the race to develop products, not on competition in the market for existing products. But the evidence was clear that both Roche and Genentech were among very few, serious participants in that development race. The merger would have substantially concentrated actual, not merely potential or speculative, R\&D efforts. In turn, the merger would have reduced the number of players in an as-yet non-existent but likely and predictable future product market.

While the evidence that innovation efforts would be consolidated makes enforcement appear warranted, it raises an interesting question about enforcement rationale. The Roche/Genentech case is presented as a case about preserving innovation incentives in the market for the drug therapies actually under development. ${ }^{102}$ But it doesn't seem quite right to explain the case as being about fostering incentives for firms to undertake innovation that was in fact already occurring. To the extent the case was about innovation, then, it seems more coherently explained as preserving a market structure that had proven itself conducive to innovation and that therefore should not be allowed to concentrate further and reduce the potential for future R\&D. If that is the underlying rationale, then the case marks a significant departure from conventional antitrust analysis. But the case could alternatively be explained as really being about conventional product-market competition, with the evidence of innovation serving to show that the merger would combine two future rivals and create higher prices when the market for the infection treatments at issue does eventually develop. That interpretation is 
still a dynamic one to which innovation is crucial, but it is in the end firmly within the traditional competitive framework of antitrust.

The Justice Department's action in the ZF/Allison case was in an important respect different from Roche/Genentech: there was no specific R\&D effort the Justice Department found would be compromised by the acquisition. But the decision indicates that where the change in concentration is so great that it leaves an industry near monopoly and without other potential sources of new developments, potential harm to the "innovation market" could justify a challenge to the transaction.

In the ZF/Allison case too, however, there is a lurking ambiguity about the underlying rationale. On the surface it seems reasonable to block a merger that would result in an 85 percent share of the world market, even if there may be fringe firms capable of introducing innovations and additional competition. In most cases such a merger would raise concerns about both allocational efficiency and innovation incentives. In ZF/Allison, the efficiency issue was absent because, although neither company was a monopolist in the global market, each had close to a 100 percent share of the specific geographical markets in which it actually did business. Consequently, few consumers would have faced a reduction in the number of competing suppliers due to the merger. The case is therefore cast as preserving innovation incentives rather than market competition.

If, however, the companies for the most part do not compete in the product market, why is there any reason to believe they compete in the "innovation market"? To be sure, monopolists still have some incentive to reduce costs and increase profits, so the fact that the two companies' do not compete in any geographical market does not mean they would not each have incentives 
to innovate. But the same logic — that innovation incentives do not necessarily depend on competition — could be applied to the merged entity and thus does not supply a rationale for blocking a transaction between non-competing entities. This does not mean the ZF/Allison decision was a bad one. It does indicate that separating innovation incentives from productmarket competition effects can be difficult and raises some of the difficulties in applying the framework designed for static competitive analysis to dynamic questions of innovation.

One possible rationale for the Justice Department's action is that, over time, it is better to have two potential innovators in the market rather than one, in order to preserve the potential for a diversity of approaches to developing new technology and to preserve the possibility for future product-market competition. The ZF/Allison decision is novel in that it preserves separate entities not for reasons of price competition, but for reasons of future innovation. In the context of a merger to near-monopoly, the idea doesn't seem so radical, but in principle it represents an important change in traditional merger analysis. The agency's focus was not on preserving innovation tied to any particular product or identifiable line of research, but instead on preserving conditions likely to be more conducive to any innovation in the market sector. The $\mathrm{ZF} /$ Allison merger, however, presents a relatively easy example of such a pure innovation case. The merger to monopoly certainly reduced the potential for competition between the two major firms. The case gives little insight however, into how the agencies would evaluate a case involving a greater number of firms in which only innovation, and not product-market competition, was at stake.

\section{B. Transitional Cases: Innovation Moves to the Fore}

The two factors that were central to the Roche/Genentech and ZF/Allison cases, very high levels of concentration and parallel, competing innovation efforts, have also formed the 
basis for several more recent merger-enforcement actions through which the relationship between antitrust and innovation has further developed.

\section{Aerospace Mergers}

The aerospace industry is one of the most innovative economic sectors in the United States. The market is characterized by high concentration levels but also, outside the defense sector, by international competition. In the late 1990's, the FTC and Department of Justice, respectively, approved one major aerospace merger and blocked another. Innovation considerations were central to these enforcement decisions.

In 1997, the FTC approved the merger of Boeing and McDonnell Douglas, the two largest commercial aircraft manufacturers in the United States. ${ }^{103}$ In that case, analysis of innovation in the aerospace industry supported the merger, not because the transaction was expected to increase R\&D, but because the analysis showed that McDonnell Douglas had fallen behind technologically and no longer could exert competitive pressure on its rivals. ${ }^{104}$ Acquisition by Boeing would therefore not reduce future competition and would allow McDonnell Douglas' assets to be put to better use by a more technologically advanced enterprise.

Concerns about progress in aerospace led to a different conclusion in Lockheed Martin's proposed acquisition of Northrop Grumman. The Justice Department's challenge to the merger explained that Lockheed and Northrop were two of the leading suppliers of aircraft and

103 See Statement of Chairman Robert Pitofsky, et al., In the Matter of The Boeing Company/McDonnell Douglas Corporation, FTC file no. 971-0051, July 1, 1997. 
electronics systems to the U.S. military. ${ }^{105}$ The Department concluded that the merger would give Lockheed a monopoly in systems for airborne early warning radar, electro-optical missile warning, fiber optic towed decoys, and infrared countermeasure systems. ${ }^{106}$ In addition, the merger would reduce the number of competitors from three to two in high-performance, fixedwing military airplanes, on-board radio countermeasures, and stealth technology. ${ }^{107}$ The Justice Department contended that consolidation in these markets would lead to higher prices, higher costs, and reduced innovation for products and systems required by the U.S. military. ${ }^{108}$

Although traditional competitive concerns about prices were an important part of the Justice Department's challenge to Lockheed's acquisition of Northrop, innovation concerns were central. For example, the Department noted that Lockheed and Northrop had both started research and development for advanced airborne early warning radar systems and concluded that consolidation of the two R\&D efforts would harm future military procurement. ${ }^{109}$ The Department also found evidence that competition is particularly important for technological advances in high-performance military aircraft and that important innovations have often been made by firms other than the incumbent suppliers of particular systems. It thus concluded that "competition is vital to maximize both the innovative ideas associated with each military aircraft program, as well as the quality of the processes used to turn innovative ideas into cost-effective, technically sound, and efficiently produced aircraft."110

U.S. v. Lockheed Martin Corp. and Northrop Grumman Corp., Complaint (D.D.C., filed 3/23/98). Ibid at 2 .

Ibid at 3.

Ibid at 3.

Ibid at 7-8.

Ibid at 26. 
The Justice Department's conclusion in the Lockheed/Northrop case that preserving competition in the relevant markets would enhance innovation was based principally on two factors that weighed against permitting the transaction: (1) evidence that Lockheed and Northrop were either actually conducting competing R\&D on important products or were the leading contenders to conduct such R\&D in the future; and (2) evidence that consolidation would lead to either monopoly or substantial dominance in relevant product markets, not just reducing, but in large part eliminating, competitive pressure. Thus, a combination of market structure and parallel innovation efforts pointed towards a likely reduction in both actual and potential innovative activity if the merger were consummated.

Lockheed/Northrop thus fits to a large extent the parameters of our Case 2 in Section II. Although a patent race was not necessarily at issue, what was at stake was the race to develop technology that would win a major government contract, another form of winner-take-all (or most) innovation contest. The Justice Department at least implicitly found that, in the aerospace/defense sector, the benefits of faster innovation and a choice of alternative technologies offset possible costs of effort duplication. There was, in addition, the possibility that, if the two technologies that the competitors developed were truly substitutes, then the government would also get the benefit of conventional product-market competition between bidders for the contract. In other words, mixed in with the innovation concern central to the case was also a more conventional, static pricing concern. ${ }^{111}$

111 Similar issues arose and conclusions were reached in the Department of Justice's challenge of a proposed merger of the only two companies that manufacture nuclear submarines for the United States. (United States of America v. General Dynamics Corporation and Newport News Shipbuilding, Inc., Verified Complaint, United States District Court for the District of Columbia, October 23, 2001.) 


\section{Biotechnology and Pharmaceuticals.}

In the mid-1990s, the FTC focused on innovation concerns in crafting a consent agreement with merging firms in the biotechnology and pharmaceuticals industry. Ciba-Geigy and Sandoz announced plans to merge into a new company now known as Novartis. The FTC raised several objections to the merger. ${ }^{112}$ Along traditional antitrust lines, the FTC was concerned the combination would give the merged entity power to reduce competition and raise prices in the markets for herbicides used in growing corn and for flea-control products for pets. ${ }^{113}$ The FTC accordingly ordered one party to divest those businesses. ${ }^{114}$ The more novel parts of the FTC's challenge, however, had to do with research and development and the prospects for future innovations in the market for gene therapy products—-products that allow treatment of diseases and medical conditions by modifying genes in patients' cells.

At the time of the FTC’s investigation in 1996 and 1997, no gene therapy products were on the market or even approved by the Food and Drug Administration. ${ }^{115}$ Conventional merger analysis therefore did not apply because there was no product market in which to analyze the merger's effects on prices and output. The FTC instead adopted a dynamic perspective; looking to the future, it found long-run competitive concerns. The sales of gene therapy products were expected to grow rapidly, with projections for a $\$ 45$ billion market by $2010 .{ }^{116}$ Ciba and Sandoz were either among very few, or the only, firms with the technological capability and intellectual

See In the Matter of Ciba-Geigy Ltd., et al., Decision and Order, FTC Docket No. C-3725, March 24, 1997.

Id.

Id..

See FTC, In the Matter of Ciba-Geigy Ltd, et al., Analysis of Proposed Consent Order to Aid Public Comment, at 3.

Id. 
property rights necessary to develop gene therapy products commercially. The FTC stated in its complaint against the proposed merger that Ciba and Sandoz were "two of only a few" entities capable of the R\&D necessary to enter the market. Together they would control essential patents, know-how, and proprietary commercial rights without which other firms, even if capable of developing gene therapy products, would be unable to commercialize them. The FTC was concerned that Novartis, the newly named post-merger company, might not adequately license its gene therapy intellectual property to assure that other firms would be able to close the R\&D gap. The FTC concluded that "preserving long-run innovation in these circumstances is critical." ${ }^{117}$

The FTC did not, however, block the merger. Instead, it crafted a consent decree designed to correct those aspects of the transaction that raised concerns for current and future competition and innovation. As noted above, divestiture of certain overlapping herbicide and flea-control businesses occurred. More interestingly, the FTC did not require divestiture of either firm's gene therapy division. Instead, Ciba and Sandoz agreed they would license technology and patents sufficient for one of its major rivals to compete against the merged entity in the development of gene therapy products. ${ }^{118}$

The FTC's remedy steered between the potentially conflicting economic effects a merger might have on research and development. On one hand, consolidating complementary capabilities can enhance innovation and allow a combination of firms to achieve what the firms individually could not do as easily. On the other hand, concentrating markets to near-monopoly levels can dampen the pressure to innovate and reduce the enhanced probability of success that Ibid, at 9 . 
comes from multiple R\&D efforts. Both concerns are reflected in the FTC's enforcement action. The FTC declined to order either Ciba or Sandoz to divest its gene therapy subsidiary because it found that R\&D efforts between the parent companies and their subsidiaries were closely coordinated, making divestiture disruptive and counterproductive for innovation. The decision instead to order compulsory licensing to a capable competitor was designed to preserve both competition and the benefits of the merging parties' relationships with each other and their respective gene therapy subsidiaries.

The market context in which the FTC's focus on innovation occurred is significant. The merger did not simply change the degree of competition within a middling range of market concentration. Rather, the combination of Ciba and Sandoz concentrated virtually all innovation efforts and essential inputs for commercialization of gene therapy under one corporate roof. Innovation concerns were sufficient to motivate enforcement because the facts showed a combination of monopoly market structure and reduction in the number of actual (as opposed to potential) innovation efforts. To some degree, this was a traditional potential entry case with respect to product-market competition. But the action also broke important new ground: it expressly recognized that a current merger could be challenged on grounds of future innovation and competition in a product market that does not yet—but likely will—exist. It is interesting to contrast this action with the ZF/Allison action. In the case of ZF/Allison, the issue was a product market with (as yet) non-existent innovation, while in Ciba/Sandoz the issue was innovation for an (as yet) non-existent product market.

\section{Recent Case Developments: More Nuanced Analysis}

The antitrust agencies' focus on innovation in merger review, which became evident in the 1990s, has continued to develop. Although most innovation cases involve advanced stages 
of innovation—so that the issue is more one of potential product-market competition than innovation for its own sake—-the Department of Justice and FTC have both also expressed interest in protecting innovation for its own sake, as the following cases illustrate.

The proposed \$16 billion merger of Hoechst and Rhône-Poulenc into the pharmaceutical company known as Aventis raised both potential and actual competition concerns for the FTC. 119 Innovation was central to the potential competition aspects of the merger. Hoechst had an existing anti-clotting product and Rhône-Poulenc was close behind, with a product almost through the FDA review process. As in Ciba/Sandoz, the FTC was also concerned about a combination of patent portfolios, in this case patents related to anti-clotting agents. In December 1999, the FTC entered into a proposed consent agreement settling its charges that the merger would violate Section 7 of the Clayton Act. The parties were allowed to merge on condition that they divest assets relating to Rhône-Poulenc's direct thrombin inhibitor drug Revasc, in order to preserve competition and the opportunity for innovation in direct thrombin inhibition as a superior treatment for blood clotting diseases. The merged entity was also required to divest its interest in a subsidiary that produced cellulose acetate in order to preserve competition in the market for cellulose acetate thermoplastics. ${ }^{120}$

The FTC again faced a mix of actual and innovation-based potential competition issues in its challenge to the Amgen/Immunex merger in 2002. ${ }^{121}$ At the time Amgen and Immunex proposed to merge, Amgen had the only IL-1 inhibitor, which is used to treat rheumatoid

Hoechst AG, FTC Docket No. C-3939 (2000), available at: www.ftc.gov/os/caselist/c3919.htm See, also, Kevin J. Arquit and Richard Wolfram (2001) "Mergers and acquisitions: United states government antitrust analysis and enforcement,” PLI Order No. B0-00Z6 May 10-11, 2001 - New York City May 1718, 2001 - Chicago May 31-June 1, 2001 - San Francisco 42nd Annual Antitrust Law Institute, at 453.

120 Hoechst AG, FTC Docket No. C-3939 (2000), available at: www.ftc.gov/os/caselist/c3919.htm Amgen Inc., FTC Docket No. C-4056 (2002), available at www.ftc.gov/os/caselist/c4056.htm. 
arthritis, on the U.S. market. Immunex and one other firm, Regeneron, were the only other companies with IL-1 inhibitors in U.S. clinical trials. The FTC feared that the combination of the Amgen and Immunex patent portfolios might allow the merged firm to block entry by Regeneron. The FTC expressed concern not only about harm to potential competition from the merger, but also about the possibility that the combination would reduce R\&D competition for related new products. The FTC nonetheless allowed the merger to proceed based upon a consent decree that required the licensing of certain patents to Regeneron. The FTC reached a similar result in its review of the Glaxo/SmithKline Beecham merger in 2001. ${ }^{122}$

The cases discussed so far may leave the impression that innovation has only been salient in mega-mergers where billions of dollars are at stake in the transaction and/or in particular market sectors, notably pharmaceuticals and defense aerospace. But that is not the case. As noted in our earlier discussion of remedies in Section IV.C, the Department of Justice sued in 2001 to block 3D Systems Corporation's proposed \$45 million acquisition of DTM Corporation, alleging that the transaction, as originally structured, would have resulted in higher prices and less innovation for industrial rapid prototyping (“RP”) systems in the United States. ${ }^{123}$ The complaint alleged that "3D and DTM offered the most sophisticated systems in the industry and competed directly against each other in the development, manufacture, and sale of industrial Docket No. C- 3990 (Dec. 18, 2000) (Analysis of Proposed Consent Order to Aid Public Comment), available at http://www.ftc.gov/os/2000/12/glaxoana.htm; Arquit and Wolfram, supra note 119, at 337339.

$123 \quad$ United States v. 3D Systems Corp. and DTM Corp., C.V. No. 1:01CV01237 (D.D.C. filed June 6, 2001). See, at: http://www.usdoj.gov/atr/cases/f8800/8896.htm (Complaint). See, also, United States v. 3D Systems, 2002-2 Trade Cas. (CCH) ๆ 73,738 (D.D.C. 2002) (Final judgment). 
rapid prototyping systems and materials”. ${ }^{124}$ The acquisition would have combined the two largest manufacturers of RP systems in the United States, reduced the number of competitors in the U.S. market for industrial RP systems from three to two, and resulted in the combined company having a U.S. market share, by revenue, of 80 percent. ${ }^{125}$ The Department of Justice settled the case through a consent decree that requires 3D and DTM to license their RP-related patents to a firm that will compete against the merged enterprise in the U.S. market. The district courts' decision entering the decree expressly discussed the merger's potential impact on innovation as well as price competition in the market for rapid prototyping systems. ${ }^{126}$

Taken together, the merger cases in which the U.S. antitrust agencies have made innovation a central issue fall mostly into the first of the abstract cases we set out in Section II above: they have involved innovation efforts sufficiently well under way that one of the merging parties can convincingly be considered a potential competitor to the other. Review of those mergers has thus fit relatively comfortably into the existing framework for merger policy. But at lease some cases have paid lip service, or even purported to base enforcement, on the preservation of innovation for its own sake in a particular industrial sector. In these cases--for example GM/ZF and 3D/DTM — the agencies did not undertake a detailed analysis of the market structures in the relevant industries that would be most conducive to innovation, nor did they examine the welfare consequences of reduced innovation in the industries at issue. In the GM/ZF case, the Department of Justice appears implicitly to have assumed that one larger firm would be worse for innovation than two already quite large enterprises would be. In the Id. United States v. 3D Systems Corp. and DTM Corp., Final judgment, at 11. 
3D/DTM case, the consolidation from three to two major U.S. firms raised concerns about innovation, although those concerns were deemed to have been allayed by the consent decree.

The cases to date therefore do not yet give a sense of how the agencies are likely to respond to transactions that fall into the second and third abstract cases that we discuss in Section II above. Approaches to cases that raise questions about which market structures will be most conducive to efficient $R \& D$, or that raise welfare tradeoffs between price competition and innovation, are not as well developed as review of cases where innovation matter solely through existing projects' effects on potential product-market competition. Merger policy’s understanding of the relationship between competition and innovation will have to be further developed, not only to identify objectionable transactions, but also to craft effective remedies, where licensing of intellectual property rights has generally been assumed to cure both the reduction in $R \& D$ and the reduction in potential competition that some mergers portend.

\section{CONCLUSION: TOWARDS DYNAMIC MERGER POLICY}

When it comes to merger policy, innovation is tricky stuff. However, antitrust enforcers have the tools to treat innovation in merger analysis. The cases in which the Department of Justice and FTC have already addressed innovation demonstrate that the agencies are sensitive to the ways that innovation can affect future competition in product markets. The use of information about innovation to support objections to a merger based on potential competition concerns does not require fundamental change to, or expansion of, the existing merger-policy framework. The harder issues for merger policy involve four kinds of problems that transactions involving innovation raise: (1) the need to assess potential product-market competition from innovation efforts still far from completion; (2) the question of whether current product sales and production capabilities are relevant to the assessment of future competition; (3) a merger's effect 
on innovation; and (4) possible tradeoffs between dynamic innovation benefits and static competition benefits.

The first issue is an evidentiary one. At what point is evidence of innovation sufficient for the agencies or courts to determine that the innovator is a predictable product-market competitor? Most of the cases to date have involved innovations that were essentially complete and undergoing trials and/or regulatory approval. But some transactions will push enforcement authorities to take a more dynamic view of potential competition. The challenge for the agencies and courts in these cases will not involve changing the existing merger-review framework, but instead involves articulating the parameters of the factual inquiry from which the agencies and courts will infer potential competition from evidence of ongoing innovation.

The second issue, whether current market shares are relevant to predicting future product-market competition, can be addressed within the standard conceptual framework codified by the Merger Guidelines, and there are well-developed economic tools for addressing the issue. However, a movement away from a predominant focus on market shares and toward a more refined analysis of industry conditions and the nature of competition would represent a dramatic change in the practice of merger litigation.

The remaining problems above are more difficult and fundamental for the existing framework on both conceptual and practical levels. The issues of the efficient amount or timing of innovation, and of the comparative values of competition today versus improved products tomorrow do not fit easily into the conventional merger review framework. Antitrust agencies could decide not to address these issues and, instead, the agencies could retain their focus on more conventional product-market concerns. But the impact of innovation on economic welfare and the impact of market structure on innovation will occur whether antitrust policy accounts for 
them or not. Hence, if the agencies chose this course, judgments about these impacts would be made implicitly and without reflection. To the extent antitrust policy makers wish to avoid the potential costs of ignoring innovation, the question becomes how antitrust agencies should proceed in incorporating innovation concerns into their mission.

The overarching lesson from our analysis is that merger policy enforcers should recognize that innovation will depend more heavily on factual inquiries specific to a given case and less on systematic presumptions of the kind merger policy has long applied to static, product-market competition. The analysis summarized above suggests several approaches that the agencies charged with developing and enforcing merger policy might use to address innovation and its potential effects in the merger review process.

First, the agencies could develop and articulate guidelines for drawing inferences of potential product-market competition from evidence of ongoing innovation. Doing so would extend the existing framework to cover a number of situations in which innovation does or many would say should play an important role in merger analysis.

Second, agencies might continue to expand their consideration of mergers' effects on innovation and consumer welfare to cases in which the concern is with potential R\&D projects that are not already underway. So far, the agencies have been cautious in moving beyond concerns about potential product-market competition based on well-defined innovative efforts. The agencies also have not made explicit tradeoffs between short-term product-market competition and innovation. The agencies could, however, consider broadening their inquiry to take these important effects into account.

Therefore, a third approach that the agencies might pursue would be to develop the expertise that would allow case-by-case, fact-intensive inquiries to assess the welfare effects and 
tradeoffs posed by mergers where innovation is at stake. Academic researchers could make an important contribution to this effort by conducting industry-specific studies that provide a deeper understanding of the history and conditions for innovation in different economic sectors regularly at issue in mergers. As observed in Sections V.B and V.E.1 above, empirical research demonstrates that industry-specific factors play important roles in mediating the relationship between concentration and firm size on the one hand and the pace of innovation on the other. Additional studies of the sort we recommend might lead to the identification of fact patterns that allow clearer understanding of how to treat innovation in the context of different kinds of transactions that come up for review.

A fourth approach would be for the agencies to make use of the tools of decision theory to deal with uncertainty, particularly with respect to innovation. Under current practice, for example, the agencies often take an approach of considering a two-year horizon in assessing the effects of entry, with little or no discounting within the horizon and complete discounting of anything beyond. ${ }^{127}$ Similarly, efficiency benefits that are realized only with a lag are "given less weight because they are less proximate and more difficult to predict.” ${ }^{„ 28}$ Standard decision theory, however, indicates that these approaches are poor heuristics for calculating expected payoffs in the face of uncertainty. For example, these approaches to entry tend to underestimate the effects of potentially revolutionary innovations that have some probability of having very large effects over a period of a number of years. The conventional decision-theoretic approach would be to estimate probability distributions for alternative potential outcomes and then use

Merger Guidelines, § 3.2. The agencies sometimes take a more sophisticated view, at least when deciding whether to file a case against a proposed merger, if not in court.

Id., footnote 37 . 
those probabilities as weights in projecting an expected net present value of a merger's effects on consumer welfare. ${ }^{129}$ More broadly, the effects of mergers on innovation are uncertain and occur over time, and the agencies and the courts have not made full use of established decision theory to structure their analyses of consumer welfare effects.

In conclusion, although a coherent and effective approach to innovation in merger policy will be difficult, the analysis suggests the goal is achievable.

129 We observe in passing that there are difficult legal issues concerning whether the courts can appropriately aggregate welfare affects across different generations of consumers. 